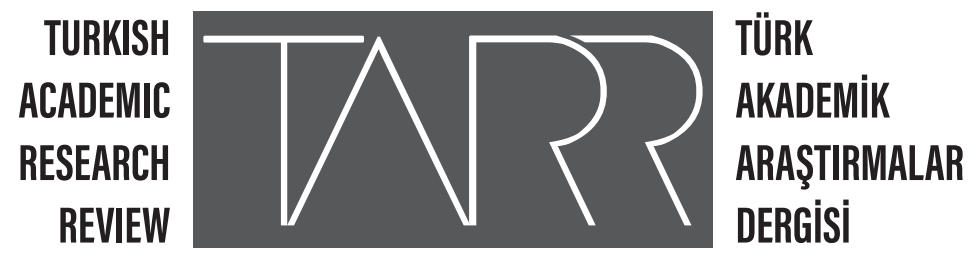

\title{
İslâm Âlimlerinin Bağımsız Düşünme ve Eleştiri Anlayışı -Emevî ve Abbasîler Dönemi-
}

Independent Thinking And Criticism Of Islamic Scholars

\begin{abstract}
Şakir Gözütok
Prof. Dr., Van Yüzüncü Y11 Üniversitesi İlahiyat Fakültesi, Din Eğitimi Anabilim Dalı Van Yuzuncu Yil University Faculty of Theology, Department of Religious Education, Van, Turkey e-mail: sgozutok@yahoo.com Orcid 0000-0001-7232-6729
\end{abstract}

\author{
Makale Bilgisi | Article Information \\ Makale Türü-Article Type | Araştırma Makalesi/Research Article \\ Geliş Tarihi-Date Received | 18 Mart/March 2020 \\ Kabul Tarihi-Date Accepted | 25 Haziran/June 2020 \\ Yayın Tarihi-Date Published | 30 Haziran / June 2020 \\ Yayın Sezonu | Nisan-Mayıs-Haziran \\ Pub Date Season | April-May-June
}

Atıf/Cite as: Gözütok, Şakir, İslâm Âlimlerinin Bağımsız Düşünme Ve Eleştiri Anlayış1-Emevî ve Abbasîler Dönemi-/ Independent Thinking And Criticism Of Islamic Scholars.tarr: Turkish Academic Research Review, 5 (2), 175-204 doi: tarr.705875

Intihal/Plagiarism: Bu makale, en az iki hakem tarafından incelenmiş ve intihal içermediği teyit edilmiştir. / This article has been reviewed by at least two referees and confirmed to include no plagiarism. https://dergipark.org.tr/tr/pub/tarr

Copyright (C) Published by Mehmet ŞAHIN Since 2016- Akdeniz University, Faculty of Theology, Antalya, 07058 Turkey. All rights reserved. 


\title{
İslâm Âlimlerinin Bağımsız Düșünme Ve Eleștiri Anlayıșı -Emevî ve Abbasîler Dönemi-
}

\begin{abstract}
Şakir Gözütok ${ }^{1}$
Bu çalışmamızda, İslâm dünyasındaki düşünürlerin özgür düşünme ortamını ve düşünceleri ifade etme özgürlükleri ile birlikte âlimlerin birbirlerini eleştirme gücünü ele almaya çalıştık. İslâm âleminde özgür düşüncenin kaynakları ile bunu ortaya koyabilme imkânları daha çok ilgilendiğimiz konulardır. Elbette özgürlüğün olduğu yerde, her türlü fikir ortaya konulabilmekte ve fikirlerin rahatça ifade edildiği ortamlarda da buna bağlı olarak serbestçe eleştiri yapma imkânı bulunmaktadır. Çalışmamızda, İslâm dünyasında bunun imkânı araştırılmıştır. Ayrıca bazı düşünürlerin, kendilerinden farklı düşünen veya fikirlerini tasvip etmedikleri kimseleri niçin ve nasıl eleştirdikleri, eleştiri veya tenkit yapılırken nelere dikkat ettikleri üzerinde de durulmuştur. Burada İslâm âlimlerinin, eleştiri metotları ile eleştiri anlayışları geniş bir şekilde ele alınmaya çalışılmıştır. Bütün bunlarla birlikte, yapılan eleştiri ve tenkitlerin hangi sebeplere dayandığ̣ konusu da ilgi alanımızdadır. Eleştiri yapılırken kişinin, mutlak surette içinde yaşadığı dönem ve kültürün etkisinden bağımsız olmadığı, bu sebeple eleştiri yapılan dönem ve eleştiri kültürünü oluşturan toplumun yapısının da önemli olduğuna vurgu yapılmıştır. Konunun sonunda genel bir değerlendirme yapılmıştır.
\end{abstract}

Anahtar Kelimeler: Din Eğitimi, İslâm, Özgür Düşünme, Eleştiri Kültürü, Eleştiri Anlayışı

\section{Independent Thinking And Criticism Of Islamic Scholars}

\begin{abstract}
In this study, we tried to examine the freedom of thought of the scholars in the Islamic world and the power of the scholars to criticize each other. The sources of free thought in the Islamic world and the possibilities to reveal this are the issues we are more interested in. Of course, where there is freedom, all kinds of ideas can be put forward, and in situations where ideas are expressed in a comfortable way, there is the possibility of making criticism freely. In addition, some thinkers have emphasized why and how they criticize those who think differently or do not approve of their ideas, and what they pay attention to when making criticism. In the meantime, criticism methods and criticism approaches of Islamic scholars have been tried to be discussed extensively. In our study, the possibility of this was investigated in the Islamic world. On the other hand, we are also interested in the reasons why criticisms and criticisms are based. When criticizing, it is emphasized that the individual is not independent from the influence of the period and culture in which he / she lived, therefore the period of cri-
\end{abstract}

1 Prof. Dr. Van Yüzüncü Y11 Üniversitesi İlahiyat Fakültesi, Din Eğitimi Anabilim Dalı Van Yuzuncu Yil University Faculty of Theology, Department of Religious Education, Van, Turkey sgozutok@yahoo.com 
ticism and the structure of the society constituting the culture of criticism are also important. A general assessment was made at the end of the topic.,

Keywords: Religious Education, Islam, Free Thinking, Criticism, Criticism Culture.

\section{Özet}

İslâm dünyasında özgür düşünme ve eleştiri kültürü, genel çerçevesini İslâm'ın genel anlayışından almaktadır. İslâm dini, "dinde zorlama yoktur" ayeti ile en sıkı bir inanç ile bağlanılan dinî meselelerde dahi başkasının zorlanamayacağını esas bir düstur olarak kabul etmiştir. Bundan hareketle herkesin yaptıkları ve düşündüklerinin, kendisini bağladığı kabul edilmiş ve buna uygun hareket edilmeye çalışılmıştır. İmam Şâfî̀n nin, bir öğrencisine "Allah seni hür yarattı, sen de yaratıldığın gibi hür yaşa”, şeklinde tavsiyede bulunması, hür anlayışın en esaslı yönüne vurgu yapmaktadır. Bu sebeple her insanın özgür doğduğu ve düşüncelerini hür bir biçimde ortaya koymasının, doğuştan getirdiği bir hak olduğu düşünülmüştür. Söz konusu fikir ve düşünce hürriyetinden istifade ederek pek çok İslâm karşıtı düşünür bile, İslâm ülkelerinde İslâm dinini acımasızca eleştirdikleri halde hem kendileri hem de eserleri varlıklarını sürdürebilmişlerdir. Hatta bu tip bazı eleştiri eserlerinin nerdeyse bir bütün olarak, İslâm âlimlerinin yazdığı kitapların içinde günümüze taşındığına da şahit olmaktayız.

Özgür düşüncenin meydana getirdiği hür bir ortamda, şüphesiz fikir üreten insanlar rahatlıkla düşüncelerini ortaya koyabildiği gibi, serdedilen bu fikirler, aynı zamanda rahatlıkla eleştirilebilmiştir. İslâm düşünürlerinin kesif çoğunluğu, bazı âlimleri ve fikirleri eleştirir ve tenkit ederken, çok seviyeli ve kibar bir üsluba sahip oldukları dikkat çekmektedir. Öyle ki bazı âlimler, eleştirdikleri şahsın fikirlerini çürütmeye çalışırlarken aynı anda fikir sahibini övmekten de geri durmamışlardır; en azından üstün meziyetlerini dile getirmeyi bir kadirşinaslık borcu olarak görmüşlerdir. Ancak her zaman eleştirinin normal şartlarda ve incitici olmayan bir üslupla yapıldığını söylemek zordur. Çoğu zaman hasmını sert ve yıpratıcı bir şekilde eleştirenleri tetikleyen veya etkileyen belli şartlar ve sebepler olmuştur, ancak yine de genel olarak İslâm âlimlerinin bir fikri eleştirirken olabildiğince objektif davranmaya çalıştıklarına şahit olmaktayız. Çoğu kez mezhep ayrılıklarının, zaman zaman sert eleştiri ve tenkitlere isnat teşkil ettiği görülmektedir. Ancak aynı mezhepten olmalarına rağmen, bazı düşünürlerin haleflerinin haksız tenkit ve eleştirileri rahatlıkla ortaya koymaktan çekinmemişlerdir. Aynı zamanda İslâm âlimlerinin, kendilerine has eleştiri metotları ve bir eleştiri üslubunu ortaya koydukları da görülmektedir. Objektif olmayı başaramayanların ise, bazı etkenlerden dolayı haksız denilebilecek eleştiriler yapmışlardır. Bu haksız eleştiriler, bir kaş sebepten kaynaklanmıştır. Bunların başında, insanların içinde yaşadıkları dönemin siyasi, ekonomik ve kültürel şartlardan kaynaklandığını rahatlıkla ifade edebiliriz. Bazı dönemlerin kendilerine has özelliklerinden kaynaklanarak çok sert eleştirilerin yapıldığını müşahede ettiğimiz gibi, şartların değişmesiyle eleştiri üslubunun yumuşadığı da vakidir. Çoğu zaman da yapılan eleştirilerin konuyu tam anlamamaktan veya konu ile ilgili eksik ya da yanlı̧ bilgiden kaynaklanan eleştiriler olduğu fark edilmektedir. Bu tür eleştirilerin bir kısmı, ya yazarın yazdığı metnin tamamı okunmadan veya bütün eserlerindeki fikirler göz önüne alınmadan aceleyle veya kasıtlı olarak yapılmıştır. Sonradan gelen âlimlerin bir kısmı, kendilerinden önceki bazı düşünürlerin muhatabını tam 
anlayamadıklarını veya yanlış anlamaktan kaynaklanan haksız eleştiriler yaptıklarını dile getirmişlerdir. Şunu da kaydetmek gerekir ki, kişilerin bağlı oldukları düşünce ekolüne taassupla bağlanmaları da, meseleleri dar bir çerçeveden ele almalarına ve bundan kaynaklı kendileri gibi düşünmeyen bazı düşünürlere haksız eleştirilerde bulunduklarına da şahit olmaktayız. Ama her halükârda İslâm âlimleri, bir kişiyi veya görüşü eleştirdiklerinde mutlaka bir delil ve destekten hareket ettiklerini de ifade etmemiz gerekir.

İslâm dünyasında ilim ve âlime duyulan üstün saygı, çoğu zaman âlimlerin ve dolayısıyla onların görüşlerinin tenkit edilmesini engelleyen bir husus olmuştur. Çoğu âlimler, istifade ettikleri hocalarını büyük bir saygı ve hürmetle anmış ve onların görüşlerini kendilerine düstur edinmişlerdir. Buna bağlı olarak ders aldıkları hocalarının görüşlerini özenle kaydetmiş ve itinayla korumuşlardır. Ahmed b. Hanbel hariç, diğer üç büyük fikıh mezhep imamına nispet edilen eserlerin neredeyse tamamı, kendileri tarafından yazılmamış, bilakis fikirlerine itimat eden öğrencileri tarafından bizlere aktarılmıştır. Ancak birkaç kuşak sonra gelen mezhep mensupları, bazı fikirleri yeniden ele alıp düzenleme ve eleştirme süzgecinden geçirmişlerdir. Özellikle Sultan Melikşah, Nureddin Zengî ve Selahaddin Eyyûbî̀nin özel gayretleri neticesinde, farklı mezheplerin bir arada eğitim gördükleri öğretim kurumlarının oluşturulması, mezhepler arasındaki gerilimin önemli bir şekilde ortadan kalkmasına sebep olmuştur. Bir arada eğitim gören faklı mezhebe mensup kimseler, kendi mezheplerinden olmayanlarla aralarında çok farklı bir düşünce ve anlayışın olmadığının farkına vardılar. Bu durum, eskiden beri aralarında var olan gerilimin ortadan kalmasına vesile olmuştur. İslâm dünyasında mezhepler arası çekişmenin ortadan kalkması ile birlikte, Müslümanların birbirlerine müsamaha ile davrandıkları ve eskiden var olan ötekileştirmenin ortadan kalktığı görülmüştür. Bu ortamın tabii bir sonucu olarak, İslâm âlimleri arasındaki tenkit ve eleştirinin de dozu değişmiş, çok az istisna hariç daha yumuşak ve saygılı bir dilin hakim olduğu görülmüştür. Âlimler yine birbirlerini tenkit etmiş ve eleştirmişlerdir, ancak doğrudan saldırgan bir dil kullanmak yerine, sadece tenkit veya eleştiri yapmakla yetinmiş, muhataplarını saygıyla anmaktan geri durmamışlardır. Nihayet şunu rahatlıkla söyleyebiliriz: İslâm dünyasında genellikle hakim olan atmosfer, özgür düşüncenin ve eleştirinin serbest olduğudur.

\section{Summary}

The culture of free thinking and criticism in the Islamic world derives its general framework from the general understanding of Islam. Islam has accepted that olarak there is no compulsion in religion as a fundamental motto that "no one else can be compelled even in religious matters" which are connected with the most firm belief. From this point of view, it was accepted that everyone's actions and thoughts were bound to him and he tried to act accordingly. The fact that Imam Shafi'i advised one of his disciples, "Allah created you free, and you live free as you are", emphasizes the most fundamental aspect of free understanding. For this reason, it is thought that every human being is born free and to express his / her thoughts freely is an innate right. Even many anti-Islamic thinkers, taking advantage of the freedom of thought and thought in question, were able to survive both themselves and their works, even though they ruthlessly 
criticized the Islamic religion in Islamic countries. We even witness that some of these critical works have been carried to the present day in the books written by Islamic scholars as a whole.

In a free environment created by free thought, people who produce ideas can undoubtedly put forward their ideas, as well as these ideas that have been spread, can also be easily criticized. While the majority of Islamic thinkers criticize some scholars and ideas, it is remarkable that they have an elegant and polite style. So much so that some scholars, while trying to refute the ideas of the person they criticized at the same time, did not hesitate to praise the author; at least they have seen expressing their superior merits as a debt of grace. However, it is always difficult to tell that criticism is done under normal circumstances and in a non-offensive manner. Often there have been certain conditions and reasons that have triggered or influenced critics of his adversary in a harsh and aggressive manner, but in general, we witness that Islamic scholars, in general, try to be as objective as possible when criticizing an idea. It is often seen that sectarian differences are sometimes attributed to harsh criticism. However, although they are from the same denomination, some thinkers did not hesitate to put forward the unjust criticism of their successors. At the same time, it is seen that Islamic scholars present their own methods of criticism and a style of criticism. Those who failed to be objective made criticisms that could be called unjust due to some factors. These unfair criticisms stem from a number of reasons. First of all, we can easily state that the period in which people live is caused by political, economic and cultural conditions. As we observe that very harsh criticisms have been made due to the peculiar characteristics of some periods, it is also evident that the style of criticism has got softened with changing conditions.

Most of the time, it is noticed that the criticisms are caused by not understanding the subject completely or from incomplete or incorrect information about the subject. Some of such criticisms were made hastily or deliberately, either without reading the entire text of the author or taking the ideas into account in all his works. Some of the later scholars stated that some of the thinkers before them did not fully understand the interlocutor or made unjust criticisms arising from misunderstanding. It should also be noted that people are tied to the school of thought with which they are attached and that they deal with the issues from a narrow framework and that some thinkers who do not think like them are unfair criticisms. However, in any case, we should also state that when Islamic scholars criticize a person or opinion, they always act from evidence and support. The high respect for science and scholars in the Islamic world has often been an obstacle to the criticism of scholars and accordingly their views. Most scholars have commemorated their professors with great respect and reverence and adopted their views as their motto. Accordingly, they carefully recorded the views of their teachers and carefully protected them. Except for Ahmed B. Hanbal, almost all of the works that were compared to the other three major fiqh sect imams were not written by them but were transferred to us by their students who trusted their ideas. However, the sect members who came after a few generations reconsidered some ideas and subjected them to a filter of regulation and criticism. In particular, as a result of the special efforts of Sultan Melikşah, Nureddin Zengî and Salahaddin Eyyûbî, the establishment of educational institutions where different sects were educated together caused the tension between the sects to disappear significantly. People from different sects, who were educated together realized that there was not a very different idea and unders- 
tanding among those who were not from their own sect. This has led to the elimination of the tension that existed between them. With the disappearance of inter-sectarian conflict in the Islamic world, it was seen that Muslims treated each other with tolerance and that the existent otherization disappeared. As a natural consequence of this environment, the dose of criticism among Islamic scholars has changed, and with a few exceptions, a softer and more respectful language has been used. Scholars criticized one another again, but instead of using a direct offensive language, they were content with criticism only and did not refrain from commemorating their interlocutors. Finally, we can easily tell that the generally dominant atmosphere in the Islamic world is free thought and criticism.

\section{Giriș}

Doğru düşünebilmek, çeşitli görüşleri gözden ve süzgeçten geçirebilmek, müstakil bir fikir sahibi olabilmek, başka düşünceleri eleştirip tenkit edebilmek için hür bir düşünceye sahip olmak şarttır. Hürriyet kelimesi Arapçada kölenin zıddı olarak kullanılmaktadır. ${ }^{2}$ Hürriyet kelimesi, aynı zamanda anlam olarak ahlâkî bir zemine de oturur. Bu yüzden hürriyet, "hırs ve onun getirdiği kötülükler gibi uygun olmayan sıfatların ve dünyevî menfaatlerin insana hâkim olmaması" olarak da tarif edilmiştir.

Batı dünyasında kanun koyuculardan biri olarak tanınan Wintrop (1588-1649) da hürriyeti şöyle açıklar: "İki türlü hürriyet var. Biri bozuk. Hayvan da, insan da kullanabilir bu hürriyeti: Hoşuna gideni yapmak. Böyle bir hürriyet, her otoriteye düşmandır, her kurala kafa tutar, aşağılatır bizi. Hakka da, barışa da karşı. Tanrı yasaklamıştır bu hürriyeti. Bir de medeni ve ahlakî hürriyet var, gücünü birlikten alan bir hürriyet. Devletin görevi, bu hürriyeti korumaktır. İşte bu kutsal hürriyet uğruna gerekirse canımızı vermeliyiz: Doğru ve iyi olan her şeyi çekinmeden yapma hürriyeti. Kiliseye göre de hürriyet ikiye ayrılır: Kutsal olan, bozuk olan. Hakkın hürriyetini kabul, hatanın hürriyetini reddeder kilise. Ama hakkın da, hakikatin de tek kaynağı: Kendisi. Kısaca, kilisenin istediği hürriyet kendi hürriyetidir."4

Kişiye, kuruma veya ideolojilere göre hürriyetin tarifi veya konumlanışı değişebilir, ancak hürriyetin ekmek ve su gibi her insanın ihtiyacı olan ve doğuştan getirdiği bir hak olduğu hiç bir zaman unutulmamalıdır. Şüphesiz insanın sahip olmak istediği pek çok hürriyet vardır; bunların başında, düşünce ve ifade özgürlüğü gelmektedir. Nitekim Ahmed Eflâkî: "Zenginlik ne para ve ne de servettedir: İlim ve hürriyettedir. Esaret zinciri boynunda ise, seni istediğin gibi düşünmekten alıkoyan ister altın tasma, ister saman artığı olsun, ne farkı eder?" 5 diye hürriyetin önemine işaret etmektedir. Düşünce hürriyetini elde edemeyenler, beyinlere geçirilmiş bir korseyle dolaşanlardır. At gözlüğü takanlar, hiç bir meseleyi ve fikri bütün cephesiyle ele

2 İbn Manzûr, Lisânül-arab, thk. Abdullah Ali el-Kebir, Muhammed Abdullah Hasbullah, Haşim Muhammed Şazelî (Kahire: Dârü'l-Me'arif, ts.), 829.

3 Ebu Kasım Hüseyin b. Muhammed b. Ragıb el-İsfehânî, el-Müfredât fî̀ garibi'l-Kur'ân, thk.Muhammed Seyyid Geylânî (Beyrut: Dârü'l-Ma'rife, ts.), 111.

4 Cemil Meriç, Mağaradakiler (İstanbul: Ötüken Yayınları, 1978), 265.

5 Cemal Kutay, Bilinmeyen Taribimiz (İstanbul: Dizerkonca Matbaas1, 1974), c. 1, s. 446. 
alamaya muktedir olamazlar. O halde ancak hür düşüncenin olduğu yerde, fikirlerin yeşermesi, tartışılması ve teatisinden söz edilebilir.

Arapların ilk filozofu unvanına sahip Kindî (ö. 259/873), Felsefe-i Ûlâ hakkında Halife Mu'tasım Billah'a yazdığı risalede, bazı eleştirilerin yersiz olduğunu ve insanların doğruların peşinde koşmaları gerektiğini şöyle dile getirir: "Bize basit menfaatler sağlayan kimseleri eleştirmemek, onlara şükran duymak, hakikatin gereğidir. Bir de, bize çok büyük faydalar sağlayan, çok yararlı hakikatleri ifade eden kimselere karşı nasıl tavır takınılmalıdır, sen düşün! Bu insanlar, hakikatin bazı yönlerinde kusur etmiş olsalar da, ortaya koydukları değerli fikirlerle, birçok bilgiye ulaşmamızı sağlayan ilimleri ile eksik kaldıkları konulara nazaran bize çok büyük yarar sağlamış, yolumuzu aydınlatmış ortaklarımızdır. Doğruya, "doğru” demekten ve onu güzel görmekten gocunmamalıyı, nereden geldiğine bakmaksızın hakikati kabul etmeliyiz, bizden farklı olan ve bize düşman olan milletlerden gelse bile... Gerçek şu ki, hakikati arayan kişi için hakikatten değerli bir şey yoktur. Ayrıca hakikat konusunda cimrilik edilmez, onu ortaya koyan kişinin değeri küçümsenmez. Hakikat kimsenin değerini düşürmez, aksine herkese şeref kazandırır." ${ }^{\prime}$ Kindî, bu risalesinde doğruyu ve hakikati dile getirenlerin, zaman zaman yanlışa düşseler bile, onlara karşı nasıl tavır alınması gerektiğine dair bazı ölçüler ortaya koymaktadır.

İslam alimleri veya ulemasından kastımız, İslam dünyasında "alim" sıfatıyla tanınmış ve yaşadıkları dönemde ilim ve ihtisas alanlarıyla şöhret bulmuş, öğrenci yetiştirmiş ve düşünce hayatımızda iz bırakmış kimselerdir. Zaten genel bir ifadeyle tarih ve tabakat kitaplarından bu kimselerden alim olarak söz edilmektedir. İslam ulemasının konumuz ile ilgili görüş ve yaklaşımlarını ele alırken bağlı bulundukları ekol ve mezhepten çok genel bir bakış açısını esas almaya çalışacağız. Kişilerin bağlı oldukları ekol, onların özgür düşüncesini veya eleştiri uslüplarını etkilemişse, özellikle buna vurgu yapılacaktır.

$\mathrm{Bu}$ çalışmada başlangıcından Abbasî dönemi sonuna kadar olan süreçte İslam ulemasının özgür düşünce ve eleştiri konusundaki tutumunu ele almaya çalışacağız. Zira bütün İslam tarihi boyunca yapılan eleştirileri ele almanın zorluğu ortadadır. Ayrıca bu dönemlerde fikrî çalkantıların en çok yaşandığ 1 dönemler olması hasebiyle zaman zaman sert eleştirilerin olduğu dönemlerdir. Kısmen bu tür eleştirilere değinmekle birlikte hakim olan genel havayı ele almaya gayret edeceğiz. Bu tür eleştirilerin nedenleri üzerinde durulmaya ve mümkün mertebe karş1laştırmalar da yapılmaya çalışılacaktır.

\section{İslâm Dünyasında Özgür Düșünce}

Kur'an'da "Dinde zorlama yoktur" (el-Bakara 2/256) ayeti, sadece din meselelerinde değil, değişik konularda zorlama olamayacağını içermektedir. İmam Sahnûn’a (ö. 240/854) göre, bu ayette yasaklanan zorlama, meşru olmayan bir şey için yapılan zorlamadır. ${ }^{7} \mathrm{O}$ halde meşru ve insan haysiyetini zedelemeyen her fikir, beyan edilme hürriyetine sahiptir. Dolayısıla Müslümanlar, bütün özgürlüklerinin ilhamını bu ayetten almaktadırlar. Ayrıca herkesin yaptıklarının

6 Kindî, Resâilu'l-Kindî el-Fesefiyye, thk. Muhammed Abdulhadi Ebu Zeyde (Mısır: Daru'l-Fikri'l-Arabî, 1950), s. 83.

7 Ebu İshâk İbrahim b. Musa b. Muhammed eş-Şâtibî, el-İ'tisâm, thk. Ebu Ubeyde Meşhur b. Hasan Âl Süleyman (Kahire: Mektebetu't-Tevhid, ts.), 3: 25. 
kendisini bağladığını ve kimsenin başkasını mutlak bir yoruma zorlayamayacağını şu ayet göstermektedir: "Boş sözü işittikleri vakit ondan yüz çevirirler ve "Bizim işlerimiz bize, sizin işleriniz de size. Selâm olsun size. Biz cahilleri istemeyiz" derler” (el-Kasas 28/55). Esasta özgürlük, İslâm dininin vaz geçemediği esaslardan biridir. İmam Şâfî̀ (ö. 204/819), kendisine tavsiye isteyen öğrencisine: "Allah seni hür yarattı, sen de yaratıldı̆̆ın gibi hür ol"8 şeklinde tavsiyede bulunması, bu hakikate işarettir. Aslında İmam Şâfî̂ bu görüşlerini, yine kendisinden rivayetle Sahabe ile ilgili şu nakilden almış olmalıdır: "Önderimiz olan Sahabeler, önlerinde bir kural ve kurallar manzumesi olsun ya da olmasın, görüşlerini en serbest ölçüler içinde ortaya koymakta idiler." ${ }^{9}$ Bu özgürlük anlayışından hareketle İslâm âlimlerinin, devlet başkanının müçtehit derecesinde biri olmasını şart koşmalarının gayesi, başkasını taklit etmek yerine özgür iradesiyle hareket edebilmesini ${ }^{10}$ göz önüne almalarındandır. Buna göre İslâm'da özgür düşünce, devlet başkanından başlamakta ve düşünebilen, düşünce üretebilen herkesi kuşatmaktadır.

Muhammed b. Hakan, hocası olan Abdullah b. Mübârek'e (ö. 181/797) "Bize tavsiyede bulunun" diye rica emesi üzerine, O’nun: "Görüşleri imam edinmeyin"11 demesi, kısmen Naslar karşısında aklî yorum ve anlayışa bir gönderme olsa da, bir yanıyla da her fikri eleştiri süzgecinden geçirmeden bağlanmamayı da ifade etmektedir. Bu hakikatten hareketle birçok İslâm âlimi, sıkı sıkıya görüşlerine bağlı oldukları mezhep imamlarını rahatlıkla eleştirebilmiş veya onların hilafına görüş beyan edebilmiştir. Bunlardan bir olan İmam Pezdevî, bağlı olduğu mezhebin önderi olarak gördüğü İmam Maturidînin Kitabu't-tevbid’ini “manada muğlak, gereksiz uzatmalar ve planında zorluk bulunduğunu" ${ }^{2}$ ileri sürerek rahatlıkla tenkit edebilmiştir. İmam Tehâvî (ö. 322/934) anlatıyor: Babam bana Ebu Ubeyd b. Harbevey'in faziletinden ve fikhî bilgisinden söz ediyordu: Bir gün bir konuda Ebu Ubeyd ile müzakere ederken, ona bir konuda bir cevap verdim ve bana: "Bu söylediğin, Ebu Hanife'nin sözü değil” dedi. Ben de ona: “Ey Kadı! Ebu Hanife'nin dediği herşeyi söylemek zorunda mıyım?” dedim. Ebu Ubeyd bana: "Ben seni yalnızca bir mukallit olarak bilirdim" diye karşılık Verdi. Ben de: "Taklit, taassup mudur?" diye sordum, o da: "Ya da Ğabîdir" dedi. Bu söz Misır'da darb-1 mesel oldu, insanların dilinden düşmedi." 13 Taklidin taassup olamayacağını, her fikir sahibinin çok rahat düşüncelerini ortaya koyabileceğini ortaya koyan bu örneğin benzelerini, çokça bulmak mümkündür. Keza Ebu Kasım Abdülaziz b. Abdullah ed-Dârikî (ö. 375/985) de, İmam Şafî̀ ve İmam Azam’n mezheplerinin hilafina bir fetva verdiğinde, kendisine bu husus sorulunca: "Filan, filandan Resulullah'tan (s.a.v.) şunu rivayet etti" der ve şöyle devam ederdi: "Hadisi almak, iki imamın görüşünden daha evladır." Oysa kendisi Şafî̀ mezhebinin fakihlerindendi. ${ }^{14}$ Bir mezhebe bağllik,

8 İmam Şâfiî Muhammed b. İdris, el-Umm, thk. Muhammed Zühri en-Neccâr (Beyrut: Dâru'l-Ma'rife, ts.), 1: B; Fahruddin er-Razî, Muhammed b. Ömer b. Hüseyin, Menâkibu’ş-Şafî̀, thk. Ahmed Hicazî eş-Şakkâ (Kahire: Mektebetu'l-Külliyâti'1-Ezheriyye, 1986), 338.

9 Cüveynî, Ebu'l-Mealî Abdülmelik b. Abdullah b. Yusuf, el-Burhan fî usûli’l-fikh (Katar: thk. ve nşr: Abdülazim ed-Dîb, 1399), 2: 1117.

10 Şatibî, İ'tisam, 3: 44.

11 Hafiz Ebubekir Ahmed b. Ali el-Hatib el-Bağdadî, Tarihu Bağdat ve medinetu's-selam (Beyrut: Dârü'l-Kutûbi'l-İlmiye, ts.), 5: 250|; İbni Kayyım el-Cevziyye, İlâmu'l-muvakkinn, thk. Taha Abdurrauf Sa’d (Beyrut: Dârü'l-Ceyl, 1973), 1: 258.

12 Ebu'l-Yusr Muhammed el-Pezdevî, Usûlu'd-din, thk. Hans Peter Linns (Kahire: el-Meketebtu'l-Ezheriyye li't-Turas, 2003), 14.

13 Kadı Ali b. Ali b. Muhammed b. Abdulizz ed-Dımaşkî, Şerhu’l-akideti't-tehavî, thk. Abdullah b. Abdulmuhsin et-Turkî ve Şuayb el-Arnaûtî (Beyrut: Müessesetu’r-Risâle, ts.), 1: 53, 54.

14 Ebu'l-Abbas Şemsuddin Ahmed b. Muhammed b. Ebibekir b. Hallikan, Vefayatu'l-a'yan ve enbau ebnai'z-zaman, thk. İhsan 
hiçbir zaman özgür düşünmeye engel ve serbest görüş bildirmeye mani olmamalıdır, nitekim bunu başarabilenlerin sayısı çoktur.

Maturidî kelam anlayışının önemli temsilcilerinden İbn Humam (ö. 861/1457), üstadı Maturidî’nin "tekvin” meselesindeki görüşünü doğru bulmayıp tenkit ettiği gibi, fiile ilişkin insan iradesinin yaratılmamış olduğunu iddia etmekle daha da cesur adımlar atar. İbn Humam, mensubu bulunduğu kelam anlayışının önderini tenkidin yanında, haklı görüşlere sahip olduğuna inandığında İmamına Maturidî mezhebine mensup olmasına rağmen, Mutezilîlerle aynı görüşte olduğunu ve Eş'arî̀yi haklı bulduğu yerlerde de onun görüşlerine katıldığını açıkça ifade etmekte bir sakınca görmez. ${ }^{15} \mathrm{Bu}$ yaklaşım, aynı zamanda hür bir anlayışa ve özgür ifadeye de işaret etmektedir. Bu meyanda Hanefî mezhebinin ve Maturidî kelam anlayışının önemli isimlerinden bir olan İmam Pezdevî, vahiy olmadan kişinin aklen Allah'ın varlığını bilmek zorunda olduğu şeklindeki İmam Ebu Hanife'nin görüşünü aktardıktan sonra, bu konuda farklı düşündüğünü, Buhara'daki Hanefî ekolü ve İmam Eş’arîyle aynı fikirleri paylaştığını rahatlıkla zikretmektedir. ${ }^{16}$

Çoğu İslâm âlimlerinde, ilmin verdiği objektif bakış açısı hâkim olmuştur; bunun örneklerine ulemasının eserlerinde çokça rastlamak mümkündür. Bu örneklerin en ilginç olanların biri şudur: Hanbelî mezhebine mensup ve bu mezhebin en önemli şahsiyetlerinden biri olan İbn Cevzînnin (ö.597/1201), yazdığı Mevzûât adlı eserinde Ahmed b. Hanbel'in Müsned inde geçen bazı Hadislerin mevzu olduğunu yazmasıdır. İbn Cevzî, mensubu bulunduğu ve kendisinin sıkı sıkıya bağlı olduğu mezhebin İmamını hakikati ifade etmek adına eleştirmekten geri durmamıştır. Buna karşılık Şafî̀ mezhebine mensup olan İbn Hacer el-Asakalânî, el-Kavlu müsedded fî̀z-zehbi ani'l-müsned li'l-imâm Ahmed adlı eserinde İbn Cevzînnin uydurma saydığ1 hadislerin mevzû olmadığını savunmaktadır. İbn Hacer, bir gerçeği ortaya koymak adına mensubu olmadığı mezhebin imamını, onun mezhebine mensup birine karşı temize çıkarmak için kaleme sarılmıştır.

İbn Mukaffa' (ö. 142/759), fîs'Sahâbe ${ }^{17}$ adlı risalesinde bunlarla nasil mücadele edilmesi gerektiğinin siyasi yönünü belirttikten sonra, devlet tarafından bir nevi resmî olarak atanıp halkı eğitecek bir ulema (öğretmenler) sınıfının kurulmasını Halife Mehdi'ye tavsiye etmektedir. ${ }^{18}$ Çünkü bu dönemde İslâm ile bağdaşmayan çok sayıda değişik anlayışlar ortaya çıkmıştır. Cahız'dan (ö. 255/869) öğrendiğimiz kadarıyla bu tip kötü niyetli kimseler, çok güzel kâğıtların üzerine güzel hatlarla kitap yazıp ve rahatça satabilmekteydiler. ${ }^{19}$ Bunların, Me'mun dö-

Abbas, 4. Baskı (Beyrut: Dâru Sadr, 2005), 3: 189; İbnu'1-Cevzî, el-Muntazam, 14: 314.

15 Sait Yazıcıŏlu, "Maturidî Kelam Ekolünün İki Büyük Siması: Ebu Mansur Maturidî ve Ebu’l-Mu’in Nesefî", İmam MaturudÎ ve Maturidîlik, Haz: Sönmez Kutlu (Ankara: Kitabiyat Yayınları, 2003), 167.

16 Pezdevî, Usulu'd-Din, 215, 216. Değerlendirme için bkz: Ulrich Rudolph, Maturidî, trc. Özcan Taşlı (İstanbul: Litera Yayınları, 2016), 456.

17 Abbasî Halifesi Mansur'un çevresinde İbahî anlayışa sahip yönetici sınıfına da 'Sahâbe' denildiğinden, kitbaına bu ismi vermiştir.

18 Bkz: İbn Mukaffa', Abdullah b. Mukaffa', Risaletu fìss-sahabe (Asaru İbn Mukaffa' içinde), (Beyrut: Dârü'l-Kutubi'l-İlmiyye, 1989), 309-323.

19 Cahız, Ebu Osman Amr b. Bahr, el-Heyevân, thk. Abdusselam Muhammed Harun, 2. Baskı (Mısır: Matbaatu Mustafa el-Babî, 1966), 1: 55, 56. 
neminde sarayda bazı tartışmalara katıldıklarını da görüyoruz. ${ }^{20}$ Bu durum, hem çok canlı bir fikir ortamına işaret etmekte hem de İslâm'ın esasları ile bağdaşmadığı halde bazı insanların fikirlerini özgürce ifade edebildikleri bir ortamının mevcudiyetini göstermektedir. İslam dünyasında bağnaz ve taassuba sahip bazı alimlerle karşılassak da, çoğu zaman alimler özgürce fikirlerini beyan ettikleri gibi, İslam'ın temel görüşlerine muarrız görüşlerin de zaman zaman dile getirilebildiği anlaşılmaktadır.

\section{Yöneticilere Karșı İfade Özgürlüğü}

İslâm dini, insanın hürriyetine ve buna bağlı olarak özgür düşünmesine, görüşlerini hür olarak ifade edebilmesine olabildiğince imkân tanımıştır. Öyle ki, dinde otorite ve kanun koyucu olan Resulullah'a (s.a.v.) karşı bile insanlar, rahatlıkla düşüncelerini ifade edebilmiş ve Resulullah'ın bazı konulardaki önerilerini gözden geçirmesini sağlamışlardır. Bir konuşmasında Resulullah (s.a.v.): "Bedir ve Hudeybiye'de bulunmuş hiç kimse cehenneme gitmeyecektir" buyurduğunda Hz. Hafsa (r.anha): "Peki Yüce Allah'ın: "Sizden cehenneme varmayacak hiç kimse yoktur" (el-Meryem 16/71) sözü nerde kaldı?” diye itiraz eder. Bu açık fikirlilik karşısında Resulullah (s.a.v.): "Allah Teâla,19.72************** "Sonra Allah’a karşı gelmekten sakınanları kurtarırız da zalimleri orada diz üstü çökmüş hâlde bırakırız” (el-Meryem 16/71) diye buyurmuştur" 21 şeklinde cevap verir. İlk etapta Allah'ın ayetiyle çelişkili gibi görünen Resulullah'ın (s.a.v.) fikirlerine karşı Sahabe, rahatlıkla kendi görüşünü beyan etme hürriyetini kullanmıştır: Sahabe hayatında, bunun örneklerini her zaman görmek mümkündür. Nitekim çokça duyduğumuz bir rivayete göre Hz. Ömer (r.a.) halife olarak minberde hutbe verirken, kadınlara verilen mehrin çokluğundan yakınır ve sınırlandırılmasını ister. $\mathrm{O}$ esnada hutbeyi dinleyen Kureyşten bir kadın itiraz eder ve neye dayanarak bunu söylediğini sorar ve ardından şu ayeti okur: "Onlardan birine yüklerle mehir vermiş olsanız dahi hiçbir şeyi geri almayın” (en-Nisa 4/120). Bu görüşe karş1lık Hz. Ömer’in cevabı şu olur: "Kadın doğruyu söyledi ve Ömer hata etti. Ey Ömer, bütün insanlar senden daha iyi biliyorlar." ${ }^{22}$ Bu muhavere, gerçek bir fikir özgürlüğü ortamına işaret etmektedir. Kadınların söz hakkına sahip olmadıkları Cahiliye günlerinin henüz geride kaldığı bir dönemde, İslâm’ın özgür ortamında bir kadın, günümüzdeki yirmi iki devletin toprağını barındıran İslâm Devleti’nin Halifesi olan Hz. Ömer'e karşı rahatlıkla fikirlerini beyan edebilmektedir.

Her zaman olmazsa da bazı alimler, siyasi erkin uygun olmayan uygulamalarına da özgürce karşı çıkabilmişlerdir. Rivayete göre Ebu Muti’ el-Belhî (ö. 199/814), Belh şehrinde kadı iken Halife Harun Reşid döneminde bütün şehirlere gönderilen bir yazıda, "Biz ona çocuk iken hikmeti verdik" (Meryem, 19/12) ayeti delil gösterilerek çocuklarından birini veliaht tayin ettiği bildirilmişti. Bunu duyan Ebu Muti’ el-Belhî, Cuma hutbesinde şiddetle karşı çıkmıştır ve

20 Cahız, el-Heyevân, 4: 442, 443.

21 Müslim Ebu Hüseyin b. Haccac el-Kuşeyrî en-Neysaburî, Sahihu'l-müslim, 2. Baskı (Beyrut: Dâru İhyâi't-Turâs i’l-Arabî, 1972), “Fedailu's-Sahabe”, 37.

22 Ebu Abdullah Muhammed b. Ahmed b. Ebubekir Şemsuddin el-Kurtubî, el-Cami' li’l-ahkâmi'l-Kur'ân, thk. Hişam Sümeyr el-Buharî (Riyad: Daru Alemi'l-Kutub, 2003), 5: 99; Ebu Hasan Ali b. Muhammed el-Amedî, el-İhkâm fî usuli'l-ahkâm, thk. Seyyid el-Cumeylî (Beyrut: Daru'l-Kitabi'l-Arabî, 1404), 4: 193. 
bu görüşünü açıkça ifade edebilmiştir. ${ }^{23}$ Keza meşhur Hadis alimi Ebu Davud'a (ö. 275/889) bulunduğu beldenin valisi, kendi çocuklarına özel Hadis öğretimi yapmasını talep ettiğinde, bunu kabul etmemiş ve "İnsanların üstünleri ile zayıfları ilimde eşittirler" 24 cevabını vererek özgürce ilmî duruşunu sergileyebilmiştir.

Ziyad b. Ebihi, Muaviye döneminde Irak Bölgesi Umumi Valisi iken, Horasan Valisi olan Hakem b. Amr el-Gifarîye hitaben: "Emiru'l-Mü’minin (Muaviye) şunları yazdı: (savaşta ganimet olarak ele geçen) altın ve gümüşleri halka dağıtmamasını ve kendisi için biriktirmesini” ihtiva eden bir mektup yazdı. Hakem ise, Ziyad b. Ebihi'ye cevaben şunları yazdı: "Mektubun bana ulaştı, diyorsun ki: "Emiru'l-Mü'minin altın ve gümüşleri halka dağıtmamanı yazdı." Oysa ben Allah'ın kitabını Emiru'1-Mü'minin kitabından (mektubundan) önce gördüm. Vallahi eğer yer ile gök bir kulun üzerinde birleşse dahi, o Allah'tan sakınırsa muhakkak ki Allah ona bir çıkı̧̧ yolu açar. Es-Selamu Aleykum.” Hakem b. Amr daha sonra insanlara bir münadi çıkararak şöyle ilan ettirdi: "Yarın mallarınız için yanıma gelin" ve ertesi günü (fey hakkı olan) bütün altın ve gümüşleri hak sahiplerine dağıttı. Bunun üzerine Muaviye, onu prangalara vurdurdu ve hapsetti; o bu prangalarla öldü ve oraya defnedildi. Halife Muaviye, Hakem b. Amr için: "O, benim düşmanımdır” derdi. ${ }^{25}$ Horasan Valisi Hakem b. Amr, Halife ve ona bağlı Genel Vali'nin Kur'ân’a aykırı uygulamasına cesurca karşı çıkabilme hakkını, İslam dininin genel anlayışından aldığı özgürlükten atmosferinden almaktadır.

Yukarıda da görülsüğü gibi, bazı zamanlar ulemanın canına mal olsa da hakikati ifade etme ve görüşlerini açıkça ortaya koymaktan çekinmeyen bir ilmi anlayış, İslam coğrafyasının çeşitli beldelerinde örneklerini vermiştir.

\section{Özgür Düșüncenin Kısıtlanması}

Genel olarak hür ifadenin öne çıkması gereken İslam dünyasında özellikle dinî esasların belli kayıtlar altına alınmaya çalışıldı̆̆ı, çeşitli fikrî sapma ve yanlış uygulamaların dinin özüne zarar verebilecği endişesi ile serbest düşünmenin önüne geçildiği zamanlar da olmuştur. Özellikle bazı alimlerin, Resulullah'ın sünnetine dair dikkat ve hassasiyetleri farklı fikirlerin ortaya konulmasının dini yozlaştıracağı endişesi taşımaların sebep olmuştur. Tarihte Ehl-i Hadis ve Rey Ekolü olarak ele alınan fikrî farklılıklara mensup kimseler arasındaki sert eleşitirlerin temeli, bu dinî hassasiyete dayanmaktadır. Özellikle Rey Ekolü’nün başını çeken İmam Ebu Hanife’ye (ö.150/767) bu meyanda çok sert ve kabul edilmesi mümkün olmayan eleştirilere rastlamaktayız. Abdullah b. Mesleme el-Karşî̀nin İmam Malik’ten aktardığg şu rivayet buna iaşret et-

23 Ebubekr Ahmed b. Ali b. Sâbit el-Hâtib el-Bağdâdî, Tarihu medineti’s-selâm, thk. Beş̧̧âr Avvâr Ma'ruf (Beyrut: Daru’1-Garbi'l-İslâmî, 2001), 9: 121,122; Ebu Abdullah Muhammed b. Ahmed b. Osman ez-Zehebî, Mizânu'l-i'tidâlfî nakdirr-ricâl, thk. Ali Muhammed el-Becâvî (Beyrut: Daru'1-Ma'rife, ts.), 1: 574, 575.

$24 \mathrm{Kad}_{1}$ Ebu Hüseyin Muhammed b. Ebi Ya’lâ, Tabakâtül-henâbile (Beyrut: Daru’l-Ma’rife, ts.), 1:162.

25 Ahmed b. Hanbel, Müsned, 3: 501 (H.No: 1467, 5869); Hakim en-Neysaburî, Ebu Abdullah Muhammed b. Abdullah, Müstedrek alâ Sabihayn, thk. Mustafa Abdulkadir Ata (Beyrut: Daru'l-Kutubi'l-İlmiye, 1990), 3: 442 (H.No: 5869); İbn Ebi Şeybe, Ebu Bekir Abdullah b. Muhammed b. İbrahim, Musannaf, thk. Hamad b. Abdullah el-Cum'a, Muhammed b. İbrahim (Riyad: Mektebetu’r-Rüşd, 2004), 10: 384 (H.No: 31180); Beyhakî, Ebu Bekir Ahmed b. Hüseyin, el-Cami' liş̧-Şu'abi’-İman, thk. Abdulali Abdülhamid Hamid (Riyad: Mektebetu’r-Rüşd, 2003), 11: 130 (H. No: 31303); İbn Sa'd Muhammed b. Sa'd b. Müni' ez-Zührî, Tabakatu'l-Kebir, thk. Ali Muhammed Ömer (Kahire: Mektebetu'l-Hancî, 2001), 9: 28. 
mektedir: "Bu iş itidal üzere devam edegeldi, taki Ebu Hanife çıkıncaya kadar, ondan sonra kıyasa başladılar, ne iflab oldular, ne de kurtuldular. ${ }^{26}$ Bu sebeple bazı ulema, Ebu Hanife'yi olumsuz cerh edici ifadelerle anmaya başladılar. Mesela: Sika değildir (lâ sikatun), güvenilir değildir (lâ me'mûnun), hadisi yazılmaz (lâ yuktebu hadisuhu), hafız değildir (leyse bi'l-hafiz), muzadaribu'l-hadistir, sahibu hadis değildir (leyse bi-sahibi'l-hadis), mürcî̂dir, şeytandır, Resulullah'ın hadislerini kendi reyiyle reddetmiştir, ${ }^{27}$ diyerek itham etmişlerdir.

Keza bu dönemlerde Mutezile ile olan fikir ayrılıklarını da bu bağlamda ele almak gerekir. İlk zamanlar Mutezile mezhebine mensup kimseler sapkın olarak kabul edilmiştir. İslam dünyasında fikrî müsamahanın hakim olduğu dönemlerde Ehl-i Sünnet Müzetezilesi diye bazı alimler hüsnü kabul göreceklerdir. Özellikle de bazı Hanefî ulema bu kategoride değerlendirilecektir. İleride değineceğimiz gibi Mürcie olarak nitelenen Hanefîler de Ehl-i Sünnet Mürciesi olarak eleştiri çerçevesinin dişına çıkarılacaktır.

İslâm dünyasında fikirlerinden dolayı takibe uğrayan, hapsedilen ve sürgün edilen âlimlere rastlamak mümkündür. Hakkında çok olumsuz rivayetlerle anılan Vali Halid b. Abdullah el-Kasrî, Vasıt'ta bir Kurban Bayramı'nda bayram hutbesini verdiğinde: "Allah kurbanlarınızı kabul etsin, benim de kurbanım Ca'd b. Dirhem'dir” diyerek, minberden iner inmez kellesini uçurmuştur. Ca'd b. Dirhem’in: “Allah, Hz. İbrahim’i halil olarak kabul etmemiştir, Hz. Musa ile konuşmamıştır” sözlerini de gerekçe olarak göstermiştir. ${ }^{28}$ Özellikle İslam tarihininde "mihne" diye ifade edilen yaklaşık on altı yıl süren dönemde, bir çok alim "Kur'an mahluk değildir" dedikleri için işkence görmüş veya öldürülmüşlerdir. Daha önce de Ca’d b. Dirhem "Kur'an mahluktur” dediği için öldürülmüştür. ${ }^{29}$ Abbasî Halifesi Me’mun, 212/833 yılında Kur'an'ın mahluk olduğunu Bağdad Valisi İshak b. İbrahim'e bir mektup göndererek devlet politikası haline getirmiştir ${ }^{30}$ ve aksi fikir beyan edenler bu dönemde ciddi sıkıntı yaşamışlardır. Hanbelî mezhebinin kurucusu Ahmed b. Hanbel de takibe uğrayanlardan biridir; öldürülmek üzere Halife Me'mun'a götürüldüğünde, halifenin ölmesi üzerine katledilmekten kurtulmuştur. ${ }^{31}$ Ahmed b. Hanbel'in kendisi de, çektiği sıkıntılara karşı bir tepki olsa gerek, mihne olayları sona erdiği dönemde vefat eden Ebu Nasr et-Tumâr (ö. 228/843) “Kur'an mahluktur” dediği için bu şahsın cenazesine katılmamıştır. ${ }^{32}$

İslâm dünyasında da zaman zaman değişik düşüncelere tahammülsüzlük görülse bile bu dinî saiklerden neşet etmekten ziyade, siyasî tercihlerden ve yöneticilerin olumsuz tavırlarından

26 İbn Abdilberr, Ebu Ömer Yusuf b. Abdilberr, Cami’u'l-beyani'l-ilm ve fadlihi, thk. Ebu'l-Eşbar ez-Zührî (Suudi Arabistan: Daru İbni'l-Cevzî, ts.), 1: 1079.

27 İbn Adiy, Ebu Ahmed Abdullah b. Adiyy el-Cürcanî, el-Kâmil fî du'afaìr-rical, thk. Adil Ahmed Abdulmevcud, Ali Muhammed Mu'avvid (Beyrut: Dârü'1-Kutubi'l-İlmiyye, ts.), 8: 235-37.

28 Selahuddin Halil b. Aybek es-Safedî, el-Vafî bi’l-vefeyât, thk. Ahmed Arnaut ve Tezkî Mustafa (Beyrut: Daru İhyai't-Turasi'l-Arabî, 2000), 11: 67.

29 İbni Kesir İmaduddin Ebu'1-Fida Hafiz, el-Bidâye ve’n-nihâye, thk. Abdullah b. Abdilmuhsin et-Turkî (Beyrut: Dârü'1-Hicr, 1997), 13: 147.

30 Ebu Ca'fer Muhammed b. Cerir et-Taberî, Tarihu't-Taberî Tarihu'r-Rusul ve’l-Mulûk, thk. Muhammed Ebu'l-Fadl İdrahim (Misir: Daru'l-Me'arif, ts.), 8: 619.

31 İbni Kesir, el-Bidâye, 14: 397.

32 Ebu'l-Ferec Abdurrahman b. Ali b. Muhammed İbnu'l-Cevzî, el-Muntazam fî taribi'l-muluk ve'l-umem, thk. Muhammed Abdulkadir Ata, Mustafa Abdulkadir Ata (Beyrut: Dârü'l-Kutûbi'l-İlmiye, 1992), 11: 139. 
kaynaklanabilmiştir. Yukarıda işaret edilen Mihne olayında olduğu igibi, değişik sebeplerle yöneticilerin tahammülsüz davranışları pek çok alimin hapis veya sürgününe sebep olmuştur. İslâm âleminde de zaman zaman sert eleştirilere muhatap olan âlimler ile eleştirilerde dozu kaçıran kimselere rastlamak mümkündür. Ancak bu durum, İslâm âleminde hiç bir zaman genel bir yaklaşım veya kabul gören bir kültür halini almamıştır.

Bazen de öne çıkan bir düşünürü çekemeyen akranları, hasetliklerinden dolayı rakip gördükleri şahısları çeşitli iftiralarla yıpratmaya çalı̧̧mışlardır. ${ }^{33}$ Ancak bunun çok genel bir uygulama olduğunu söylemek zordur. Romanyalı Panait İstrati, Osmanlı Devleti'ndeki hürriyetten söz edince benzer ifadeler kurar: “Dünyanın en hür diyarı Osmanlı ülkesidir, Tanrı'ya ve Padişah'a çatmadıktan sonra insan orada her şeyi yapmak serbesttir." 34 Çoğu zaman Allah'a ve Hz. Peygamber'e alenî bir saldırı ve haksızlık yapılmadıkça herkes fikirlerini ifade etmekte serbesttir.

\section{İslâm Âlimlerinin Eleștiri Metodu}

Eleştiri metodolojisi, eleştiren kişinin fikirleri daha iyi anlamasını ve bu anlayışı başkalarına aktarmasını sağlayan araçtır. Her ne kadar belli bir standardı ve fizikî ölçümü sağlayan bir kriteri olmazsa da; bir eleştiri metodolojisi, fikirlerle insanlar arasındaki etkileşimi sağlayan bir kavram veya kavramlar dizisidir. ${ }^{35}$ Biz de burada, bu anlayışa uygun olarak İslam ulemasının eleştiride bulunurken nasıl bir metodoloji ve üslûbu izlediklerini ortaya koymaya çalı̧̧acağız.

İslâm dünyasında ilim ve âlime duyulan üstün saygı, çoğu zaman âlimlerin ve dolayısıyla onların görüşlerinin tenkit edilmesini engelleyen bir husus olmuştur. Çoğu âlimler, istifade ettikleri hocalarını büyük bir saygı ve hürmetle anmış ve onların görüşlerini kendilerine düstur edinmişlerdir. Buna bağlı olarak da, ders aldıkları hocalarının görüşlerini özenle kaydetmiş ve itinayla korumuşlardır. Ahmed b. Hanbel hariç, diğger üç büyük fikıh mezhep imamına nispet edilen eserlerin neredeyse tamamı, kendileri tarafından yazılmamış, bilakis fikirlerine itimat edilen, hafızalarının güçlülüğü ve titizlikleri ile bilinen öğrencileri tarafindan bizlere aktarılmıştır. Ancak birkaç kuşak sonra gelen mezhep mensupları, bazı fikirleri yeniden ele alıp düzenleme ve eleştirme süzgecinden geçirebilmişlerdir.

İslâm âleminde fikir üretenlerin, düşüncelerini hür bir biçimde ortaya koyabilmeleri, aynı zamanda bu fikirlerin özgürce eleştirilebilmesini de sağlamıştır. Çünkü bir fikri açıkça ve serbestçe ifade edebilmek veya bir fikri eleştirebilmek için mutlaka özgür bir ortama ihtiyaç vardır. Bununla birlikte İslâm âlimleri, bazı düşünce ve görüşleri eleştirdiklerinde, olabildiğince objektif davrandıkları ile ilgili elimizde çokça materyal bulunmaktadır. Burada dikkat çeken şey, kadim ulemanın itiraz edeceği veya eleştireceği görüşleri ve fikirleri, tarafsız bir şekilde bütün yönleriyle ortaya koymasıdır. İslâm uleması, bir fikri eleştirmek istediğinde herhangi bir saptırmaya gitmeden, minimize etmeden ve de rahatsız olmadan olduğu gibi karşıt görüşleri ifade ettikten sonra eleştirmeye çalışarak bunu başarmıştır.

33 Örnek için bkz: Tâcuddîn Ebu Nasr Abdulvahhab b. Ali b. Abdilkafî es-Subkî, Tabakâtǚşş̧âfiîyyeti'l-kübrâ, thk. Mahmud Muhammed et-Tanahî, Abdulfettah Muhammed el-Hulvî (Kahire: Dâru İhyai'l-Kutubi'1-Arabî, ts.), 4: 209.

34 Cemil Meriç, Mağaradakiler (İstanbul: Ötüken Yayınları, 1978), 273.

35 Karlyn Kohrs Campbell, Critiques of Contemporary Rhetoric (Belmont, Ca.: Wadsworth Publishing Company, 1972), p. 12. 
Günümüzde pek çok dinî anlayışın ve İslâm mezheplerinin fikir ve görüşlerini en teferruatlı şekilde Şehristânînin (ö. 548/1153) el-Milel ve’n-nihâl adlı eserinden öğrenme imkânını buluyoruz. ${ }^{36}$ Hatta günümüzde mevcut olmayan bir çok firkanın görüşlerini dahi bu eser sayesinde olabildiğince açık ve tarafsız bir şekilde öğrenmiş bulunmaktayız. Şehristânî, hiçbir saptırmaya veya gizlemeye gitmeden bütün fırkaların görüşlerini objektif bir şekilde izah etmeye çalıştıktan sonra, bu görüşlerin yanlı̧ ve sapkın yönlerini ortaya koymaya çalışmakta ve eleştirlerini yapmaktadır. Keza kelamî görüşleriyle şöhret bulmuş çok yönlü bir âlim olan Bakıllânî’nin değişik eserlerinde ve mezhep taassubuyla itham edilen Bağdâdînin (ö. 429/1038) el-Farku beyne'l-firâk ${ }^{37}$ adlı eserinde, çeşitli firkaların dünya görüşlerini bütün ayrıntıları ile tarafsız bir şekilde bulmak mümkündür. Bu zatlar, karşı oldukları fikirleri tarafsız bir şekilde ortaya koyduktan sonra çeşitli yönlerden tenkitlerini sıralamışlardır. Özellikle Bîrûnı̂’nin (ö. 440/1048), Fî tahkik mâ li'l-Hind ${ }^{38}$ adlı kitabı da bu açıdan zikredilmesi gereken bir eserdir. Bu eserin objektifliğini, Annemarie Schimmel'in ifadeleriyle aktarmalıyı: "Avrupa'da karşılaştırmaları dinler tarihi mefhumu ortaya çıkmadan çok önce, dünya çapında yabancı bir kültürü peşin hükümsüz müşahade eden ilk eserdir.” ${ }^{39}$

Bu konuda İmam Gazzâlî, bizlere çok güzel bir örnek ve metot vermektedir. Gazzâlî, Mekâ sidü'l-felâsife $e^{40}$ adlı eserinde çeşitli felsefi anlayışları hiçbir şekilde tenkit etmeden olduğu gibi bütün açıklığıyla ortaya koyduktan sonra, bu görüşleri tenkit eden bir başka müstakil eser kaleme almıştır. Tehâfitül-felâsife ${ }^{41}$ adını verdiği bu eserinde yaptığı tenkitlerle, İslâm dünyasında uzun süre felsefenin tartışıldığ bir ortamın oluşmasına sebep olmuştur. O halde eleştiri metotlarından biri de, önce karşı fikirleri olduğu gibi ve doğru bir şekilde anlamak, sonra eleştirmektir.

Öteden beri ulemamız, İslâm'ın aleyhine de olsa bütün fikirleri ve delilleri hiçbir sansüre tabi tutmadan açık bir şekilde ortaya koymayı bir ilim haysiyeti olarak kabul etmişlerdir. Hakikati gizlemenin, hakikati inkâr kadar yanlış bir tutum olduğunun farkında olarak, bunu bütün samimiyetleriyle gerçekleştirmişlerdir. Meşhur İtalyan oryantalist Leone Caetani'nin İslâm Taribi adlı beş ciltlik hacimli eserindeki iddia ve isnatlarının çoğunu İslâm alimlerinin kaleme aldığ1 kaynaklardan toplamıştır. Bu iddialara M. Asım Köksal, Müsteşrik Caetani’nin Yazdĭ̆ı İlâm Taribindeki Isnad ve İftiralara Reddiye adlı (bazılarınca haksız bir eleştiri olarak görülen ${ }^{42}$ ) bir eser kaleme almak suretiyle cevap vermeye çalışmıştır. Çok iyi biliyoruz ki Caetani'nin ortaya attığı iddialar, İslâm aleyhine yorumlansa bile İslâm âlimlerinin ilim haysiyeti adına kendi eserlerinde muhafaza ettikleri görüşlere dayanmaktadır. Bu da, İslâm âlimlerinin kendi inançları ve hatta Peygamberlerinin aleyhinde dahi olsa hiçbir ilmi görüş ve fikrin kaybolmasına firsat tanımadıklarını göstermektedir. Bunun en dikkat çekici bir örneğini İbn Hazm, vermekte-

36 Ebu'l-Feth Muhammed b. Abdülkerim b. Ebibekr Ahmed eş-Şehristânî, el-Milel ve’n-nihâal, thk. Emir Ali Mehnâ, Ali Hasan Fa'ûr, 3. Baskı (Beyrut: Dârü'l-Ma’rife, 1993).

37 Ebu Mansur Abdülkahir b. Zahir b. Muhammed el-Bağdâdî, el-Farku beyne'l-firâk, thk. Muhammed Osman el-Haşî (Kahire: Mektebetu İbn Sinâ, ts.).

38 Bîrûnî, Ebu’r-Reyhân Muhammed b. Ahmed, Fî tahkîk mâ li'l-hind (Matbaâtu'Meclisi Dâireti'l-Me'ârifi'l-Osmâniyye, 1958).

39 Annemarie Schimmel, Doğudan Batıya, trc. Ömer Enis Akbulut (İstanbul: Sufî Kitap Yayınları, 2017), 357.

40 Ebu Hamid Muhammed b. Muhammed el-Gazzâlî, Mekâsidü’l-felâsife, thk. Mahmud Dubeycu (Dımaşk: Matbaatu'l-Debbah, 2000).

41 Ebu Hamid Muhammed b. Muhammed el-Gazzâlî, Tehâfitü'l-felasife, thk. Süleyman Dünya, 8. Baskı (Kahire: Dârü'1-Me'arif, ts.).

42 Şaban Öz, “Asım Köksal'ın Caetani Reddiyesi Üzerine”, İslâmî Araștırmalar Dergisi, 17/3 (2004): 162-170. 
dir. el-Muhallâ diye şöhret bulmuş eserinde, ${ }^{43}$ bazı sahabelerin Tebük dönüşünde Resulullah'a (s.a.v.) suikast düzenlediklerine dair uydurma rivayeti, aslı astarı olmadığı halde sadece böyle bir sözün ifade edilmiş olması bile, ilim haysiteti adına onu kitabına kaydetmekte bir sakınca görmemiştir.

Bazı İslâm âlimleri de, nezaketen muhatabının ismini zikretmeden görüşlerini ele alıp eleştirmişlerdir. Bunun en bariz örneğini İmam Buhârî̀de buluyoruz. Hadis Ehli’nden biri olarak İmam Buhârî, Rey ekolünden İmam Azam’ın bazı görülerini eleştirmek istediğinde Ebu Hânife'nin ismini anmaz, yalnızca "Bazı insanlar şöyle diyorlar" diyerek İmam Azam’ın fikirlerini eleştirir. ${ }^{44} \mathrm{Bu} \mathrm{da}$, bizlere bir tartışma, eleştirme nezaketini ve üslubuna dair naif bir örneği göstermektedir.

\section{İslâm Âlimlerinin Eleștiri Anlayıșı}

Eleştirel düşünme “ifadelerin doğru değerlendirilmesi” anlamına gelir. Eleştiri yapıldığında, ne zaman doğru değerlendirme yapılabilir ve kime göre yapılmaktadır, sorusu her zaman akılları meşgul etmektedir. Dahası, eleştirel düşüncenin ne anlama geldiği açıkça belli değildir, çünkü bir kişi eleştirel bir ifadeyi de eleştirel olmadan doğru bir şekilde değerlendirebilir veya bunu şans eseri de yapabilir. Ayrıca eleştirel düşünceye izin veren, ancak zorunlu olarak ifadelerin değerlendirilmesini gerektirmeyen birçok aktivite ve beceriler de vardır. ${ }^{45} \mathrm{O}$ halde eleştirel düşüncenin sınırları ve amacı belli olmalıdır. Eleştiri, mutlaka bir karşı delile ve argümana dayanmalıdır. Aksi takdirde eleştirinin sınırı ve düzeyini tespit etmek mümkün olamaz. Eleştirel düşünme, bilgiyi etkili bir şekilde kullanma, değerlendirme ve kazanmayı ifade etmesinin yanında, tutarlı, uygulanabilir ve yeterli olması gibi özellikleri de taşıması lazımdır.

İlimde hür düşünmeye sahip olmayı başaranlar, ancak müstakil fikirlere sahip olabilirler. $\mathrm{O}$ halde bir kimse, özgür düşünceye sahip olduğu andan itibaren başkalarının fikirlerine ram olmadan, kendine ait görüşleri rahatça ifade edebilme ve yanlış fikirleri eleştirme ve tenkide tabi tutma özgürlüğünü elde edebilir. İnsanların yetişme tarzı, çevresi, aldığı eğitim ve zekâ seviyeleri farklı olduğundan, meseleleri algılama ve değerlendirme şekilleri de farklılık göstermektedir. Kişiler arasındaki bu tarz farklılıkların sonucu olarak ortaya çıkan fikir ayrılıkları, çok az kimse tarafindan tolere ve tahammül edilse bile, çoğu zaman değişik sebeplerle çok çetin tenkit ve eleştirilere sebep olmaktadır. Eleştiri ve tenkidin türünü ve dozunu belirlemede, kişinin şahsî özelliklerinin yanında, içinde yaşadığg kültürün ve dönemin, mensubu bulunduğu grubun ve inancın da büyük bir etkisi vardır. İlginç bir örnek olması hasbiyle İbn Ravendî diye bilinen Ahmed b. Yahya b. İshak (ö. 298/910), bütün aykırı düşüncelerine rağmen hiçbir tarize maruz kalmadan fikirlerini rahatllkla beyan edebilmiştir. İbn Ravendî, el-Damiğ adlı risalesinde Kur'an'a hücum etmesine ve ez-Zümürrüdde de İslâm'ın temel öğretisi ve peygamberlik fikrini eleştirip Hz. Muhammed’in (s.a.v.) peygamberliğini iptal etmeye kalkışmasına rağmen,

43 İbn Hazm, Ebu Muhammed Ali b. Ahmed b. Said b. Hazm el-Endelûsî, el-Îsâl fî̀l-Muhallâ bi'l-Âsâr, thk. Abdulgaffar Süleyman el-Bindârî (Bayrut: Daru'l-Kutubi'l-İlmiyye, 2003), 12: 160.

44 Örnek için bkz: Buharî, Ebu Abdullah Muhammed b. İsmail, Sabihu'l-buharî (İstanbul: Mektepetu'l-İslâmî, ts.), “Zekât”, 65; "Hibe", 37.

45 John E. McPeck, Critical Thinking and Education (New York: Routledge, 1981), 2, 3. 
İslâm Devleti’nin Başkenti Bağdat'ta seksen yıl yaşamıştır. Buna karşılık bir çok İslâm âlimi, kendisine reddiyeler yazarak fikirlerini çürütmeye çalışmışlardır. ${ }^{46}$

İslam dünyasında başta kelam olmak üzere tartışma ve eleştiriyi esas alan Cedel diye isimlendirilen ilmi bir geleneğin var olduğunu ifade etmemiz gerekir. Çoğu zaman ya ilim meclislerinde ya da Halife veya Sultanların huzurunda bu tür münazara ve cedel toplantıları yapilırdı. $\mathrm{Bu}$ tartışma toplantılarının bir kısmı, sonradan kitaplaştırılarak halkın istifadesine de sunulmuştur. Bunun en ilginç örneklerden birini Halife Harun Reşid zamanında Hüsniye adındaki cariye ortaya koymuştur. Bu cariye, ilim alanındaki üstün bilgisinden dolayı Halifenin huzurunda gerçekleştirilen ilim meclislerindeki münazaralara rahatlıkla katılırdı. Ebu'l-Futuh erRazî (563/1168), bu cariyenin söz konusu ilim meclisindeki imametle ilgili münazarada ortaya koyduğu görüşlerini ele aldığı Farsça bir eser kaleme almıştır. ${ }^{47}$ Ebu Hayyan et-Tevhidî de, el-Mukābesât ${ }^{48}$ adlı eserinde hocası Ebû Süleyman es-Sicistânî̀nin evinde düzenlenen felsefe toplantılarını bir araya getirmiştir. Ayrıca el-İmtấ ve'l-múânese ${ }^{49}$ adlı eserinde de Tevhîdî, Vezir İbn Sa'dân'ın yanında bulunduğu sırada onun ortaya attığı meseleler etrafında gelişen ve otuz dokuz gece devam eden ilmî, edebî ve felsefî sohbetleri, dostu Ebü'l-Vefâ el-Bûzcânînin isteği üzerine kitap haline getirerek ona ithaf etmesiyle meydana getirmiştir. Bu tür eserler, hür düşüncenin çok rahat bir şekilde ifade edildiği ortamların mevcudiyetine de birer örnek teşkil etmektedir. İslam aleminde tartışma ve eleştirlerin yoğun olduğu özel oturumların yapılması adeta bir gelenek halini almıştır. Bu anlamda çeşitli konuların tartışıldığ "meclisu'n-nazar" (münazara meclisi) denirdi. Bir örnek teşkil etmesi bakımından Ebu Cafer Muhammed b. Ahmed es-Semnanînin (ö.344/955) kendi evinde düzenlediği münazara meclislerini ${ }^{50}$ ifade edebiliriz.

\subsection{Eleștirinin Üslubu}

Âlimler arasındaki eleştiri, tenkit ve tartışmanın mutlaka bir edebi ve usulü olmalıdır. Her eleştiri, tenkit veya tartışma mutlak surette karşı fikirdeki insanı küçük düşürmek, ilzam etmek veya susturmak amacına yönelik değildir. Tartışmada, eleştiride ve fikir teatisinde asıl gaye, gerçeği ortaya koymak ve hakikati bulmak olmalıdır. Buna işaret etmek üzere İmam Şafiî: "Hiç kimseyle asla galip gelmek için tartışmadım, hep bakikatin karşımdakinin ă̆zından çıkmasını istedim ${ }^{\prime \prime 1}$ demiştir. Madem gaye gerçeği bulmaktır, varsın karşıdaki onu dile getirsin, fark etmez. Çünkü düşünürler ve âlimler, birer hakikat avcısıdırlar; hakikatin nerden geldiğine değil nasıl elde edilebileceğine bakmalıdırlar.

Pek çok İslâm âliminin, bir başka düşünürün görüşünü eleştirirken saygılı bir dil kullandığ1, eleştirinin kişiliğe yönelik değil fikirlere karşıllk olduğunu izhar eden bir tutum içinde olmuşlardır. Söz gelimi İmam Gazzâlî, İmam Ebu Hânife'nin “zina suçuna dört şahit ayrı ayrı

46 Safedî, el-Vafî bi’-vefeyât, 8: 151-155.

47 Ömer Rıza Kehhale, A'lamu'n-nisa fî̀ âlemi'l-Arab ve'l-İslam (Beyrut: Müessesetu'r-Risale, ts.) 1: 264.

48 Ebu Hayyan et-Tevhidî, el-Mu囚ābesât, thk. Hanna et-Tendûlî, 2. Baskı (Kahire: Daru Se'adi’s-Sibah, 1992).

49 Ebu Hayyan et-Tevhidî, el-İmtâ円 ve’l-mu囚ânese, thk. Heysem Halife et-Ta’imî (Beyrut: el-Mektebetu'l-Asriyye, 2011).

50 İbnu'l-Cevzî, el-Muntazam, 14: 100; 15: 338.

51 İbnu'l-Cevzî, el-Muntazam, 10: 31; Ebu Zekeriya Muhyiddin b. Şeref en-Nevevî, el-Mecmu' şerbu'l-mühezzeb li’ș-şirâzî, thk. Muhammed Necib el-Muti'î (Cidde: Meketebetu'l-İrşad, ts.), 1: 30; Fahruddin er-Razi, Menâkibu'ş-Şafîi, 360, 361. 
yönlerden şahitlikte bulunsalar, şahitlikleri kabul edilir” görüşünü tenkit eder, ama bu görüşün Ebu Hânife'nin “Müslümanları yalancı çıkarmanın çirkin, doğrulamanın ise güzel olması” hükmünden hareket ettiğine de işaret etmeden geçemez. ${ }^{52} \mathrm{Bu}$ ifadeler, bir görüş tenkit edilse bile hakkı teslim etmenin daha evla olduğu dersini vermektedir. Keza Hanefî mezhebine mensup İmam Serahsî de, görüşlerine katılmadığı halde ünlü eseri el-Mebsût ttta İmam Şafiî̀den söz ettiği her yerde onu rahmetle anmaktadır. ${ }^{53}$

Birbirlerini eleştiren ve çekiştiren İslâm âlimleri arasında bazı zamanlar çok hoş ve mizahi olaylar da yaşanmıştır. Halife Mehdi'nin huzuruna girmek için izin istedikleri bir esnada, doğuştan kör olan meşhur Arap şairi Beşşâr b. Bürd'e Mehdi'nin hizmetinde bulunan el-Mu'alli b. Tarif: "Rabbin, bal arısına şöyle ilham etti: "Dağlardan, ağaçlardan ve insanların yaptıkları çardaklardan (kovanlardan) kendine evler edin” (en-Nahl 16/68), Allah'ın bu ayeti hakkında ne düşüyorsun? diye sorduğunda, Beş̧̧̂r: "Bu bildiğimiz arıdır" diye cevap verir. Bu cevap karşısında el-Mu'alli: "Yazıklar olsun Ey Eba Muaz, buradaki arı Haşimoğullarıdır ve: "Onların karınlarından çeşitli renklerde bal çıkar. Onda insanlar için şifa vardır" (en-Nahl, 16/68) ayetinde geçen "karınlarından çıkan da ilimdir" deyince, Beşşâr: "Allah bana gösterdi ki, yiyeceğinde şifa vardır, Haşimîlerin karnından çıkanları kana kana yiyebilirsin” diye karşılık verir. Sonra olay Halife Mehdi'ye iletildiğinde o kadar gülmüştür ki, gülmekten karnını tutmuştur. ${ }^{54}$

Ünlü edebiyatçı Esmầî (ö.215/830), atlar ile ilgili bir kitap yazınca, aralarında sürekli bir çekişme olan Ebu Ubeyde ise, buna karşılık olsun diye atlarla ilgili elli fasikül tutan bir eser kaleme almıştır. Halife Harun Reşid, ikisini imtihan için yanına çağırır ve yanlarına bir at getirttir. Ebu Ubeyde, kendisine gösterilen atın bazı organlarının asıl ismini bilemez. Esmầ î ise, atın her organının üzerine elini bıraktıktan sonra Arap şiirinden o organ ile ilgili örnekler verir. Bunun üzerine Harun Reşid, söz konusu atı Esmâ'îye hediye eder. Esmâ'î, sürekli kendisini eleştiren ve çekiştiren bu şahıs için: "Ebu Ubeyde'yi her defasında kızdırmak istediğimde, bu ata binip onun yanına gideceğim" der. ${ }^{55}$ Keza Ahmed b. Muhammed el-Meydânîn ${ }^{56}$ (ö.518/1124), Kitabu'l-Câmi' fîl'-Emsâl adlı kitabını yazdığında, kitabın güzelliğini çekemeyen meşhur edip ve müfessir Zamahşerî, eline kalem alarak (o zamanlar elle yazılan) Meydânî isminin önüne bir "nun” harfi koyarak "Nameydânî” yapar. Bunun anlamı Farsça'da "bir şey bilmeyen” demektir. Meydânî, bunun farkına vardığında, o da Zamahşerînnin bazı kitaplarını alarak, Zamahşerî̀deki "mim” harfini "nun” olarak değiştirir ve "Zanahşer̂̂” yapar; bunun da anlamı "eşinin müşterisi” demektir. ${ }^{57}$ Böylece birbirlerini zaman zaman eleştiren ve çekiştiren bu âlimler, insanı tebessüm ettiren hareketlerle birbirlerine yüklenmeye çalışışlardır. Keza Muhammed b. Hasan en-Nakkâş (ö.351/962), Kur'an harfleri konusunda âlim ve Kur'an tef-

52 Ebu Hamid Muhammed b. Muhammed el-Gazzâlî, el-Mustasfâ min ulumi'l-usûl, thk. Hamza b. Züheyr Hafız (el-Medinetu'l-Münevvere, ts.), 2: 483, 484.

53 Birkaç örnek için bkz: Şemsuddin es- Serahsî, el-Mebsût (Beyrut: Dârü'l-Ma’rife, ts.), 1: 14, 15, 19 vd.

54 Ebu'l-Ferec Ali b. Hüseyin el-İsfehanî, Kitabu'l-eğanî, thk. Abdullah Ali Maha (Beyrut: Dârü'l-Kutubi'1-İlmiye, ts.), 3: 109, 110 .

55 İbnu'l-İmad Şihabuddin Ebu Ferec Abdulhayy b. Ahmed b. Muhammed el-Akrî ed-Dımaşkî, Şezeratu'z-zeheb fî abbari men zeheb, thk. Abdulkadir el-Arnaut, Mahmud el-Arnaut (Beyrut: Dâru İbni Kesir, 1986), 3: 77.

56 Meydân, Nişabur'da bir mahalle adıdır.

57 Şihabuddin Ebu Abdullah Yakut b. Abdullah el-Hamevî, Mu'cemu'l-udeba irşadu'l-erib ilâ ma'rifeti'l-edib (Beyrut: Dârü'l-Kutubi'l-İlmiye, 1991), 2: 512; Ebu'l-Berakât Kemaluddin Abdurrahman b. Ahmed el-Enbarî, Nüzhetu'l-elbâ fî̀ tabakati'l-udebâ, thk. Muhammed Ebu'l-Fadl İbrahim (Kahire: Dârü'l-Fikri'l-Arabî, 1998), 377. 
siri hafızıydı. Nakkâş, bir tefsir kaleme almış ve ismini "Şifau's-Sudûr" koymuştur. Nakkâş'ın aynı zamanda Hadis konusunda yalancı olduğu ve çokça kıssa anlattığı da rivayet edilir. Talha b. Muhammed en-Nakkâş, onun hadislerinin münker olduğunu ve tefsirini de sahih bulmad1ğını söyler. Hibetullah el-Taberî ise: "Nakkaş'ın tefsiri, Şifau's-Sudûr (Gönüllerin Şifası) değil, İ̧̧fau's-Sudûr (Gönülleri Delen)dir” diyerek bu eseri eleştirmiştir. ${ }^{58} \mathrm{Bu}$ tür ince göndermelerle ve imalarla yapılan eleştiri örnekleri bir hayli fazladır. Cafer b. Zübeyr, Şamlıdır, sonradan Basra’ya göç etmiştir; fazilet, ibadet ve gazve sahibi biriydi. Cafer b. Zübeyr ile İmran b. Cedir aynı mescitte ders verirlerdi. Şu'be bunlar için şunları demiştir: "En doğru kimse ile en yalancı adam aynı mescittedirler." 59 Yine Kahire'deki Kâmiliye Medresesi’nde bir zamanlar İbn Dihye'nin ders verdiği kürsüye cahil birinin atanmasını, İmam Makrizî: "Buraya ancak suretiyle insandan ve konuşmasıyla da hayvandan ayırt edilebilen bir çocuk atandı”60 diyerek tenkit etmiştir.

İbn Sinâ'nın felsefeye yönelmesi ile birlikte pek çok âlim, kendisini acımasızca eleştirmiştir. İlmi konularda İbn Sinâ, ne bir rakip ve yenilgiyi ne de bir meydan okumayı kabul etmezdi. İbn Sinâ, kendisi için "Arap dilini bilmiyor” şeklinde bir eleştiri ve aşağılanmayla karşılaştığında, bu hakarete cevap vermek amacıyla Ezherî’nin Tebzibül-Luğa'sını ezberlemiş ve ünlü yazarın üslûbunu taklit eden üç risale yazıp bunları kendisini aşağılayan kişiye göndermiştir. Karşıdaki kişi ise, bu risalelerin birer taklit olduğunun farkına dahi varamamıştır. ${ }^{61} \mathrm{Bu}$ tarz kişilikleri zedelemeden, hakir görmeden, fikirlerinin ve görüşlerinin yanlışlı̆̆ını ortaya koyan ince düşünce ve üstün zekâ ürünü eleştiri ve tenktler karşısında, ilmî ahlâk sahibi âlim, her türlü saygıyı hak etmektedir.

Mezhep taassubunun bazı hakikatleri görme ve gerçeği ifade etmeye engel olmasına rağmen, hakikat aşığı bazı âlimler, doğruyu dile getirmek adına kendi mezhep imamlarını çekinmeden eleştirebilmişlerdir. Bunlardan biri olan İ̀mam Eş'arî, Bağdat'a geldiğinde, Ahmed b. Hanbel'in öğrencisi Ebu Muhammed el-Berbehârînin (ö.329/940) yanına gelir ve şunları söyler: "Ben Cübbầî̀nin görüşlerini çürüttüm, Mecusilerin ve Hıristiyanların görüşlerini de çürüttüm.” Bunu duyan Ebu Muhammed el-Berbehârî, "Ne dediğini bilmiyorum, biz ancak Abmed b. Hanbel'in dediklerini biliriz” der. Buradan ayrilan İmam Eş'arî, kendisi Hanbelî mezhebine bağlı olduğunu defalarca dile getirmesine karşılık, bu bağnazlığı ortadan kaldırmak adına el-İbâne adlı kitabını kaleme almıştır. ${ }^{62}$ Bu kitapta ortaya konulan fikirlerin ince bir eleştiri içermesi bakımından ilk etapta niçin yazıldığını fark ettirmeyecek kadar nazik bir uslüba sahiptir.

Eleştiride zaman zaman ölçüyü kaçıran ve hasmını sert bir şekilde tenkit edenlere de rastlanmaktadır. Sefih ve İbahîlerden olan ünlü şair Hammad Acrad ile gelmiş geçmiş dâhi Arap şairlerinden en meşhurlarından biri olan Beşşâr b. Bürd arasında birbirlerini eleştiri ile birlikte

58 Bağdâdî, Tarihu Bağdâd, 2: 606; Sem’ânî, Ebu Sa’d Abdülkerim b. Muhammed. B. Mansur et-Temimî, el-Ensâb, thk. Abdurrahman b. Yahya el-Mu'allimî, 2. Baskı (Kahire: Mektebetu İbn Teymiyye, 1980), 12: 130.

59 İbn Hibban Ebu Hatim, Sabibu İbn Hibban bitt-tertibi ibn balban, Telif: Alauddin Ali b. Balban el_Farisî, thk. Şuayb Arnaut (Beyrut: Müessesetu'r-Risale, ts.), 1: 250.

60 Makrizî, Takiyuddin Ebu'l-Abbas Ahmed b. Ali b. Abdilkadir, el-Mevaizu ve'l-i'tibar bi zikri'l-hitat ve'l-asar, thk. Halil el-Mansur (Beyrut: Dârü'l-Kutubi'l-İlmiye, 1998), 2: 375.

61 Dimitri Gutas, İbn Sinâ’nın Mirası, Der: Cüneyt Kaya (İstanbul: Klasik Yayınları, 2004), 9.

62 Zehebî, Şemsuddin Ebu Abdullah Muhammed b. Ahmed b. Osman, Siyeru a'lami’n-nubelâ, thk. Şuayb Arnaut (Beyrut: Müessesetu'r-Risale, 1984), 15: 90. 
hicveden şiirlerle ateşlenen "dil savaşı" tam on yıl sürmüştür. ${ }^{63}$ Çok sert ve yıkıcı bir dile sahip olan Beşşâr'dan bu sebeple herkes çekinmiştir. Beşşâr öldüğünde, yas tutmak yerine Basralılar kutlama yapmışlardır. ${ }^{64}$

\section{Eleștiri Kültürüne Dönemin Etkisi}

İslâm'ın ilk dönemlerinde âlimler, fikirlerini rahatça ortaya koyabilmekte ve yanlış bildikleri düşünceleri de kolaylıkla eleştirebilmekteydiler. Şüphesiz bu durum, olabildiğince geniş bir fikir yelpazesinin oluşmasına katkı sağlamıştır. Bu münasebetle daha Tabiûn döneminde on farklı mezhebin ortaya çıktığını görmekteyiz. ${ }^{65} \mathrm{Bu}$ durum da, açık fikirliliğin ve serbest düşünmenin ürünüdür. Ancak bu olumlu havanın çok uzun sürdügüüü söylemek imkânından mahrumuz. Zira mezheplerin ortaya çıkmasıyla beraber, zamanla hem mezheplerin dini temsil ettiği ve hem de farklı düşüncenin dinin esaslarını yok edeceği zehabından hareketle ortaya çıkan ve taassuba dayanan bir ortamın oluştuğu görülmektedir.

Mezheplerin oluşum döneminde İmam Şâfî̀, bazı İslâm ülkelerinde Mâlikî mezhebine mensup kimseler ve özellikle Endülüs'tekiler vasıtasıyla, İmam Mâlik’ten kalan eserlerin, eşyanın ve elbiselerinin takdis edildiğini duyar. Bunun sonucu olarak Müslümanlar arasında kendilerine Resulullah'ın bir hadisi söylendiğinde, ona karşı Mâlik'in sözleriyle mukabele ve muaraza edenlerin çıktığını duyunca, ${ }^{66}$ kendini tutamayıp hata da edebilen bir müçtehit olan Mâlik'in görüşlerini tenkit ile işe başladı. İmam Şâfiî, bununla İmam Mâlik’in de bir insan olması hasebiyle, hem hata yapabileceğini hem de doğruya isabet edebileceğini ortaya koymaya çalışmıştır. Çünkü bir konuda Hadis varken, O'nun görüşünün bir hükmü olamazdı. İmam Şâfiî, bu konuda bir kitap yazarak ona "Hilâfu'l-Mâlik" adını verdi. Bununla birlikte üstadı Mâlik'e hürmeten kitabı meydana çıkarmakta tereddüt etmiştir, ${ }^{67}$ fakat taassubun sebep olacağ1 zararlara engel olmak adına bir müddet sonra kitabını piyasaya sürmüştür.

Çoğu kez âlimler arasında çeşitli vesilelerle yapılan eleştirilerin dozu ve şiddetini, içinde yaşadıkları dönemin şartlarında aramak gerekmektedir. Özellikle fikhî mezheplerin ortaya çıktığ1 dönemlerde, çok geçmeden mezhepler arasında ciddi bir rekabet ve çekişmenin olduğunu fark etmekteyiz. Mezhepler arasındaki çekişmenin ve çatışmanın örneklerine başka bir çalışmamızda yer verdiğimizden ${ }^{68}$ burada detaylara girmeyeceğiz. Ancak şuna işaret etmek gerekir ki, çoğu âlimlerin otobiyografileri okunduğunda mutlaka mezheplerinin belirtilme ihtiyacı duyulduğu; bir müddet sonra da, sadece bir mezhebe bağl1 âlimlerinin tanıtıldığı "Ta-

63 Melhem Chokr, İslâm’ın Hicri İkinci Asrında Zındıklık ve zındıklar, trc. Ayşe Meral (İstanbul: Anka Yayınları, 2002), 374.

64 Chokr, Zindıklık ve zindıklar, 394.

65 Abdurrahman Celaluddin es-Suyutî, Nuzulu İsa fî ahiri'z-zaman, thk. Sa'd Kerim ed-Dir'amî (İskenderiye: Dâru İbn Haldun, ts.), 9, 10 .

66 Endülüs'te Malikî mezhebine bağlı halk: "Biz Allah'ın Kitabı Kur’ân ile İmam Malik’in Muvatta adlı eserinden başka kitap tanımayız” der ve başka bir şey söylemezlerdi.” Bkz: Philip K. Hitti, Siyasi ve Kültürel İslam Taribi, trc. Salih Tuğ (İstanbul: İFAV Yayınları, 2011), 701.

67 Muhammed Ebu Zehra, İmam Şafî̀, trc. Osman Keskioğlu (Ankara: D.İ.B. Yayınları, 1987), 29.

68 Şakir Gözütok, "İslam Dünyasında Medreseler ve İhtisas Medreselerinin Doğuşu”, Uluslararası Medreseler ve Modernleşme Sürecinde Medreseler Sempozyumu (Muş: Muş Alpaslan Üniversitesi Yayınları, 2012), 2: 8 vd. 
bakât" kitaplarının yazıldığı ve yalnızca bir mezhebin anlayışının öğretildiği eğitim kurumlarının oluştuğu gözden kaçmamaktadır.

Şüphesiz mezhebe bağlllı̆ğn çok ciddiye alındığg ve önemsendiğini dönemlerde, her âlim, bir mezhebe mensubiyetiyle birlikte anılmakta veya kendisini bu şekilde ortaya koymaktadır. Hatta yapılan bazı uygulamaların bu çerçevede değerlendirildiğine de şahit olmaktayız. Söz gelimi Hanefî mezhebine mensup ve Halep tarihinin meşhur yazarı İbn Âdim, Nizamülmülk'ün uygulamalarını mezhep taassubuna bağlamakta ve Nizamülmülk'ün mensubu bulunduğu Şafî̂ mezhebinin yaygınlaşmasını sağlamak için Şafiîleri müderris, Hanefî mezhebi gelişmesin diye Hanefî ulemayı kadı olarak kasıtlı bir şekilde atadığını iddia etmektedir. ${ }^{69}$ Nizamülmülk ile aynı mezhepten olmasına rağmen İmam Subkî, ünlü vezirin mezhep taassubunu itiraf etmektedir. $^{70}$

Görüş ayrılığının çekişmeleri ve tartışmaları alevlendirdiği dönemlerde, çok sert eleştirilerin vuku bulduğu da gözlenmektedir. Özellikle ilk dönemlerde Ehl-i Hadis ile Ehl-i Rey arasında meydana gelen gerilim daha sonra diğer fikhî mezhepler arasında da görülecektir. Ehl-i Hadis'ten bazı ulemanın, Ehl-i Rey'den saydıkları Ebu Hânife hakkında çok set eleştirilerde bulundukları dikkat çekmektedir. Öyle ki İmam Mâlik'in, Velid b. Müslim'e hitaben: "Memleketinizde Ebu Hânife konuşmaya devam ediyor mu?” diye sorduğunda, O’nun da “evet” demesi üzerine, "Onun memleketinizde oturması uygun değildir" dediği rivayet edilir. ${ }^{71}$ Hammâd b. Seleme, Ebu Hanife'nin Resulullah'ın hadislerini reyi ile reddeden bir şeytan olduğunu dahi söyleyebilmiştir. ${ }^{72}$ Taassuptan kaynaklanan eleştirilerin bu kadarla sınırlı kalmadı̆̆ını, neredeyse kendisi gibi düşünmeyenlerin varlığına tahammül edemeyecek bir raddeye vardığını nadir de olsa görmekteyiz. Hanefî mezhebine mensup et-Türkî diye meşhur bir dönem Şam Kadılığ1 yapmış olan Muhammed b. Musa el-Belasâğûnî (ö.506/1112): "Elimde yetki olsaydı Şafî̀lerden cizye alırdım” diyebilmektedir. ${ }^{73}$ Bu zat, Mâlikîlere de aynı derecede düşmandı. ${ }^{74}$ Bilindiği gibi "cizye" Müslüman olmayanlardan alınan bir vergi çeşididir. Ama bir müddet sonra bu taassup havası dağıldıktan sonra, yine Hanefî mezhebinden olan ve Hanefî âlimlerin hayat hikâyelerini toplayan bir eser yazan İbn Kutluboğa, Belasâğûnînin hayatını anlattığı eserinde: "Şayet bu isimdeki âlimlerin adlarını yazmak zorunda olmasaydım, bu akılsızca sözleri eden kişiyi kitabıma almazdım"75 demekten kendini alamamıştır.

Keza mezhepler arasında ciddi çekişmenin yaşadığı dönemlerde yaşamış meşhur kelam alimi İmam Maturidî, mensubu bulunduğu Hanefî mezhebinin görüşlerini savunmak amaciyla zaman zaman maksadını aşan ifadeler kullanabilmiştir. Şafî̀ mezhebinin görüşlerini eleştirir-

69 İbn Adim Sahib Kemaluddin b. Ahmed b. Ebi Cerade, Buğyetu't-taleb fî taribi Haleb, thk. Süheyl Zekâr (Beyrut: Dârü'l-Fikr, ts.), 5: 2494 .

70 Subkî, Tabakatu'ş-Şafî̂yyeti'l-Kübrâ, 7: 296, 297.

71 İbn Adiy, el-Kâmil, 8: 237.

72 İbn Adiy, el-Kâmil, 8: 239.

73 Muhyiddin Ebu Muhammed Abdulkadir b. Muhammed el-Karşî, el-Cevahiru'l-madiye fî tabakati’l-hanefiye, thk. Abdulfettah Muhammed el-Halvi, 2. Baskı (Beyrut: Dâru'l-Hicr, 1993), 3: 375; Ebu'1-Fidâ Zeybuddin Kasım b. Kutluboğa es-Sudûnî, Tacu't-teracim, thk. Muhammed Hayr Ramazan Yusuf (Dımaşk: Dârü'l-Kalem, 1992), 2: 60.

74 İbni Kesir, el-Bidâye ve'n-nihâye, 16: 217; Şemsuddin Ebu Abdullah Muhammed b. Ahmed b. Osman b. Zehebî, Taribu'l-islâm ve vefayatu'l-meşahir ve’l-a'lâm, thk. Ömer Abdusselam Tedmurî (Beyrut: Dârü'l-Kitabi'l-Arabî, 1993), $35: 148$.

75 İbn Kutluboğa, Tacu't-teracim, 250. 
ken, İmam Şafî̀ nin inkârlı sulhu caiz görmemesi görüşünü tenkit ederek “Şeytan, Müslümanlar arasında düşmanlık ve nefret çıkarmakta, inkârdan sonra sulhu batıl sayan kadar başarılı olamamıştır. Çünkü bu, insanlar arasında nizaların uzayıp gitmesine sebep olur"76 sözü, bazı Hanefî ulemayı dahi rahatsız etmiştir. İmam Serâhsî (ö. 483/1090), el-Mebsût adlı fikıh kitabında ${ }^{77}$ yaklaşık bir buçuk asır sonra, İmam Maturidînnin bu sözünü naklettikten sonra, onun bu sözleri karşısında suskundur, fakat İmam Şafî̀’nin neden bu hükme vardığını delilleriyle anlatarak adeta rahatsızlığını dile getirmektedir. Serâhsînin yaşadığı çağda mezhepler arasındaki buzlar henüz tam olmasa da çözülmeye başlanmıştı. Bu dönemin genel havasının Serâhsînin tutumuna yansıdığı gözden kaçmamaktadır.

Başta Sultan Melikşah olmak üzere Nureddin Zengî ve Selahuddin Eyyûbînnin özel gayretleri neticesinde farklı mezheplere mensup ilim ehlinin aynı çatı altında eğitim gördükleri medreseleri inşa etmeleri ile birlikte bu tefrika ortadan kalmış ve sosyal barış ortamı oluşturulmuştur. Böylece çok geçmeden dört fikıh mezhebinin bir arada ders gördükleri medreseler İslâm dünyasında boy göstermeye başlamasıla, mezhep arasındaki buzlar erimiş, farklı görüşte ve mezhepte olan Müslümanlar, birbirlerine tahammül edebilmiş ve olduğu gibi kabullenmişlerdir. Mezhepler arasındaki bu tarz sıcak ilişkilerin gelişmesinden sonra tenkit ve eleştirilerin de yumuşadığını ve üslubun değiştiğini görmekteyiz. Mesela Fahruddin Râzî, namazda Fatiha'nın okunması ile ilgili meseleleri ele alırken, İmam Azam'ın "Namazda Fatiha'yı namazda okumak vacip değildir” sözünü ele alırken, "Ebu Hanife'nin Muğire b. Şu’be'den gelen Haber-i Vahide dayanarak abdest esnasında başı meshetmeyi namazın şartlarından saydığı halde, Resulullah'ın ömrü boyunca namazda Fatiha okuduğu bilindiği halde bunu şart koşmaması acaip bir durumdur” diyerek Ebu Hanife'nin bu görüşünü çok kibar ve nazik bir şekilde tenkit etmektedir. ${ }^{78}$ Hatta buna tenkit demenin bile ağır geleceğini ifade etmeliyiz, zira Râzî sadece şaşkınlığını dile getirmekle yetinmektedir. Kaldı ki Fahruddin er-Râzî mensubu olduğu Şafî̀ mezhebinin kurucusu İmam Şafî̀'yi de zaman zaman rahatlıkla tenkit edebilmiştir. ${ }^{79}$

Çekişmenin puslu havası dağıldıktan sonra bazı istisnalar hariç olmakla birlikte insanların, suhulet ve sükûnetle meseleleri tartışmaya başladığına şahit olmaktayız. Bazı âlimler, geçmişte yapılan eleştirilerin sertliğinden yakınmakta ve bu üslubu aşırı gördüklerini dile getirmekten çekinmemişlerdir. Buhârî, Müslim, Ebu Davud ve Ahmed b. Hanbel'in kendisinden Hadis rivayet ettikleri ${ }^{80}$ Yahya b. Mu'in (ö.233/847): "Bizim arkadaşlarımı, Ebu Hanife ve arkadaşları hakkında ifrata düştüler" 81 itirafinda bulunmuştur. Bu itirafta Yahya b. Mu'in yalnız değildir, Mâlikî mezhebine mensup İbn Abdilberr (ö.463/1071) de: "Hadis ehli Ebu Hanife'yi kötüleme konusunda ifrata düştüler ve bu konuda haddi aşt1lar" ${ }^{2}$ diyebilmektedir. Zira O'nun mensup olduğu mezhebin kurucu imamı olan İmam Mâlik: "Tedavisi olmayan hastalık, dinde

76 Şükrü Özen, “İmam Ebu Mansur el-Maturidînnin Fikıh Usûlünün İnşâsı”, İmam Maturudî ve Maturidîlik, Haz: Sönmez Kutlu (Ankara: Kitabiyat Yayınları, 2003), 211.

77 Şemsuddin es-Serâhsî, el-Mebsût (Beyrut: Daru'l-Ma'rife, ts.), 20: 139.

78 Râzî, Fahruddin b. Diyauddin Ömer,Tefsiru'l-kebir (Mefatibu'l-gayb), (Beyrut: Dârü'l-Fikr, 1981), 1: 195.

79 Râzî̀, Tefsiru'l-kebir, 1: 68.

80 Zehebî, Siyeru A'lami'n-nubelâ, 11: 72.

81 İbn Abdilberr, Cami'u'l-beyani'l-ilm, 1: 1081.

82 İbn Abdilberr, Cami'u'l-beyani'l-ilm, 1: 1080. 
helake götürür; Ebu Hânife de, tedavisi mümkün olmayan bir hastalıktır"83 diyebilmiştir. İbn Abdilberr, kendi mezhep imamının aksine görüş ortaya koymak suretiyle, hakikati teslim etmekten çekinmemiştir.

Mezhep taassubundan dolayı ünlü Mu’tezilî âlim ve düşünür Câhız, bazı âlimleri zındıklıkla suçlamıştır. Bu meyanda: “İbn Mukaffa', Muti’ b. İyâs ve Yahya b. Ziyâd dinleri konusunda töhmet altındaydılar” demektedir. Bazıları da, Câhız ile olan mezhebî ayrılıklarından dolayı: "Câhız kendisini zikretmeyi unutmuş mu?" 44 demişlerdir.

Keza Hanbelî mezhebinden olan İbn Cevzî, İmam Azam'ı değişik konularda eleştirmiştir; 85 yine Şafiî mezhebinden olan İmam Gazzâlî̀yi ve özellikle İhyau Ulûmi’d-Din adlı kitabını da acımasızca eleştirmekten çekinmemiştir. Bunun için I'lamu'l-İhyâ bi Ablâti'l-İhyâ adlı müstakil bir eser kaleme almıştır. İmam Subkî ise, Gazzâlî̀ye yapılmış benzeri haksız eleştirilere uzun uzadıya cevap vermeye çalışmıştır. ${ }^{86}$ Pek çok İslâm âlimi, gerçekleri dile getirmek adına, fikrini ele aldı ̆̆ 1 kişinin mensup olduğu mezhep veya meşrebe aldırmaksızın eleştirmiş veya savunabilmiştir.

Bazen de Kindînnin yaptığı gibi, çağın genel havasının ve tutumunun verdiği rahatsızlıktan dolayı, bir dönemdeki ulema toptan eleştiriye tabi tutulmuştur. Kindî, çağdaşı olduğu ulema için şunları söyler: "Bunlar haksız yere işgal ettikleri kürsüleri korumak için elde edemedikleri ve çok uzağında bulundukları insanî faziletlere sahip olanları aşağılarlar. Amaçları riyaset ve din tacirliğidir. Oysa kendileri dinden yoksundur. Çünkü bir şeyin ticaretini yapan onu satar, sattığ 1 ise artık kendisinin değildir. Kim de din tacirliği yaparsa onun dini yoktur. Gerçekte varlığın hakikatinin bilgisini (felsefe) edinenlere karşı çıkan ve onu küfür sayanın dinle ilişkisi yoktur." 87

\section{Yanlıș Anlama Veya Bilgisizlikten Kaynaklanan Eleștiri}

Bazı durumlarda insanlar, herhangi bir konuda görüş beyan edenlerin fikirlerini tam anlayamadan, ya da yanlış anlamadan dolayı tenkit etme yoluna giderler. Oysa eleştirilecek bir konunun veya fikrin, enine boyuna incelendikten ve irdelendikten sonra şayet gerekliyse bir eleştiri ve tenkide tabi tutulması gerekir.

İmam Gazzâlî̀nin felsefeye yaptığı eleştirinin İslâm dünyasındaki tesiri iyi bilindiği ve bu sebeple felsefeye karşı bir duruşa sahip olmasıyla ünlendiği halde, Gazzâlı̂̀yi felsefede kaybolmuş diye eleştirenlere de rastlanmaktadır. Bunlardan biri Mâlikî mezhebinin önemli isimlerinden olan ve doğuya seyahat ederek İmam Gazzâlî’den ders alan İşbiliye Kadısı Ebu Bekir b. Arabîdir (ö.543/1148). İbn Arabî, hocası Gazzâlîye bazı konularda muhalefet eder ve şunları söyler: "Şeyhimiz Gazzâlî, felsefenin derinliklerine dalmış, sonra oradan çıkmak istemiş ama

83 İbn Adiyy, el-Kâmil, 8: 237.

84 İbn Hallikan, Vefayat, 2: 151.

85 İbn Cevzî, Muntazam, 8: 131-143.

86 Subkî, Tabakât, 6: $240 \mathrm{vd}$.

87 Kindî, Felsefî Risaleler, trc. Mahmut Kaya (İstanbul: İz Yayınları, 1994), 4. 
çıkamamıştır." 88 Bu sözleriyle İbn Arabînnin, Gazzâlîyi ya tam anlamadığ1 veya Gazzâlînnin bazı konularda felsefî metotları kullanmasını yanlış anladığı ortaya çıkmaktadır.

$\mathrm{Bu}$ tür karşıdakinin görüşlerini yanlış anlamadan dolayı eleştiriye başvuranlardan biri de, son dönem âlimlerden olan Ahmed Emin'dir. Ahmed Emin, Buhârî̀nin Sabił’indeki “Yüzyıl sonra yeryüzünde nefes alan hiçbir canlı kalmaz" ${ }^{\prime 99}$ hadisini tarihi gerçeklere uymadığ1 için tenkit ve inkâr etmiştir. ${ }^{90}$ Hâlbuki Çoşkun'un da işaret ettiği gibi Sahỉ’in başka bir yerinde, başka bir varyantla ve bu hadisi şerh eden bir rivayet, söz konusu müşkili çözmektedir. Hadis şöyledir: "Yüzyll sonra bugün nefes alanlardan (hayatta olanlardan) hiç kimse kalmaz." A1 Ahmed Emin acelecilikle, hadisin Buhârî tarafindan kısaltılarak verilen şeklini görmüş ve hemen tenkide yönelmiştir. Aynı hadisle ilgili olarak, rivayetin bütünlüğünü kaçıranlardan birisi de İbn $\mathrm{Ku}-$ teybe'dir (ö.276/889). Bununla beraber İbn Kuteybe, doğrudan Hadisi ve Buhârî̀yi eleştirmemiş, ravîlerden kaynaklanması muhtemel yanlışları göz önünde bulundurarak, hadisi şöyle yorumlamıştır: "Şüphesiz bu hadiste, ravîler ya bir kelime düşürmüş, ya unutmuş, ya da Resulullah kısık bir sesle söylediği için o kelimeyi duyamamışlardır. Bizim kanaatimize göre, hatta şüphe yok ki, Hz. Peygamber şöyle buyurmuştur: "O gün yeryüzünde "sizden" nefes alan hiçbir canl kalmayacaktır." Bu suretle Hz. Peygamber o mecliste bulunanları veya Sahabileri kast etmiştir. Ravîler ise, "sizden" kelimesini düşürmüşlerdir." ${ }^{2}$ Aslında İbn Kuteybe'nin yorumları, hadisin doğru anlaşılmasını sağlamakla beraber, bu yorumlara gerek kalmadan da bütüncül bir bakışla aslı bulunabilirdi. ${ }^{93}$ En azından daha sonraki dönemlerde söz konusu hadisi eleştirenler, mesela Tirmizî̀nin Sünen'ine bakabilselerdi, daha ilk y1llardan itibaren bu hadisi yanlı̧̧ anlayanların olduğunu ve İbn Abbas'in (ö. 68/687) söz konusu yanlışı düzelttiğini görürlerdi. İbn Abbas, Hadis hakkında yanlış değerlendirmeleri duyunca; Resulullah'ın söylediği "Şu an yeryüzünde bulunan hiç kimse kalmaz" 94 şeklindedir, diye açıklama yapmıştır. ${ }^{95}$ Dolayısıla Ahmed Emin ile İbn Kuteybe, meseleyi iyice tetkik etmeden aceleyle ilk gördüğü metni yanlı̧̧ anlayıp Buhârî̀yi haksız yere eleştirmişlerdir. Yanlış anlama veya anlamadan yapılan eleştirlerin örnekleri, bu makalenin sınırlarını zorlayacak kadar çoktur.

\section{Sonuç}

Müslüman âlimler, Kur'an ve Resulullah'ın (s.a.v.) miras bıraktığı düşünce meydanında zaman ve olayların el verdiği ölçüde özgürce fikir beyan etmişlerdir. Aslında İslâm âlemindeki itikadî

88 İbn Teymiyye, Ebu'1-Abbas Takyiddun Ahmed b. Abdülhalim, ed-Der'u te'aridi'l-akl ve'n-nakl, thk. Muhammed Reşad Salim (Medine: Vizeratu’t-Ta’limi'l-Alî, 1991), 1: 5.

89 Buharî, "İlim" 41; "Mevâkit", 20.

90 Ahmed Emin, Fecrü'l-islâm (Beyrut: Dârü'l-Kitabi'l-Arabî, 1969), 103, 104.

91 Buharî, "Mevâkit", 40.

92 İbn Kuteybe, ed-Dineverî, Kitabu te'vîli mubtelefíl-hadis (Kahire: Mektebetu'l-Mütenebbî, ts.), 66.

93 Bkz: Müslim, "Fedailu's-Sahabe”, 53; Ahmed b. Hanbel, el-Müsned, 2. Baskı (Beyrut: Dâru İhyai't-Turâsi'1-Arabî, 1993), 1: 93; 3: 322.

94 Tirmizî, Ebu İsa Muhammed b. İsa, Sünenu't-tirmizî, thk. Ahmed Muhammed Şakir (Beyrut: Dâru’t-Turâsi'l-İlmiye, ts.), "Fiten", 64.

95 Selçuk Coşkun, Hadise Bütüncül Bakı̧̧ (İstanbul: İFAV Yayınları, 2011), 62, 63. 
ve fikhî mezheplerin çeşitliliği, bu alandaki uzman âlimlerin özgürce fikir yürütmeleri sonucunda ortaya çıkmıştır.

İslâm dini, temelde Allah'a ve Resulullah'a mutlak itaati emreden bir dindir. ${ }^{96}$ Bir başka ayette Allahu Teâla ve Resulullah (s.a.v.) ile birlikte Ulu'l-Emr'e de itaat emredilmektedir. ${ }^{97}$ Başta Sahabeden İbn Ebi Talha, Abdullah b. Abbas ve Cabir b. Abdullah olmak üzere birçok alim, ${ }^{98}$ ulu'l-emr ifadesini, "âlimler" şeklinde anlamışlardır. Bu sebeple, İslâm aleminde alimlere ve özellikle kendilerine ilim öğreten hocalara karşı büyük bir saygı ve itaat vardır. Bundan dolayı çoğu düşünürler, kendi hocalarının hiçbir sözünü kaçırmamaya ve özenle kaydetmeye çalışmı̧̧lardır. Söz gelimi, Mâlikî mezhebinin temel kaynaklarından biri olan el-Müdâvenetül-Kübrâ adlı fikıh eseri, İmam Sahnun'un, İmam Mâlik'in öğrencisi Abdurrahman b. Kasım el-İtkî'den hocasının yani İmam Mâlik’in görüşlerini sorması üzerine derlenen ve elimizde bulunan haliyle muazzam bir eserdir. ${ }^{99}$ Keza İmam Şafî̂ adına elimizde bulunan en temel fikıh kaynaklarından bir olan el-Umm adlı eseri de, İmam Şafî̀nnin öğrencisi el-Müzenî ve İhtilafu'l-Hadis adlı eseri ise, Rafi' tarafından alınan notlarla bizlere ulaşmıştır.

Böyle olmakla birlikte alimlerimiz, hocalarının veya mezhep imamlarının yanıldıklarını veya yanlışa düştüklerini düşündüklerinde, onları edeple eleştirmekten çekinmemişlerdir. Zira düşünce, özgür bir ifadenin meyvesidir. Fikir adamı, tefekkür erbabıdır; düşünür, derinleşir, yeni ve özgün düşünceler üretir. Yeni bir şeyler söylemek için fikirde derinleşmek gerekir, zira inci-mercan deryaların dibindedir; kıyıda dolaşanlar, ancak çakıl taşları toplarlar. Bu münasebetle ilim ehli, fikirde ve düşüncede seçici olmak zorundadır. Düşünce ve fikirde yanlışa düşmemek adına düşünürler, hiç bir zaman eleştirmekten geri durmamalıdırlar.

Aslında eleştiri ve tenkit oklarından kurtulabilen insan sayısı çok azdır. Çocuk babasını, hoca öğrencisini, öğrenci hocasını hasılı herkes, herkesi eleştirmiştir. Eflatun da vefasız şakirdi Aristo’yu eleştirirken: "Anasının memelerini kuruttuktan sonra, ona tekmeler savuran bir taya" benzetir. ${ }^{100}$ Oysa kendisi de, fikirlerinin önemli bir kısmını borçlu olduğu Mısır için aynı vefasızlığı gösterir. Bazen eleştiri sanıldığından çok daha derin yaralar açar ve unutulmaz izler de bırakabilir. Mesela Shakespeare, eserine bir fert olarak aldığı, Hıristiyan olmadığından (Yahudi) dolayı ötekileştirdiği Schlock’a kötü bir karakter yüklediğinden, bu isim İngiliz diline "güvenilmez" anlamında bir kelime olarak geçmiştir.

Bazen de bilgisizlik veya yanlış anlamadan kaynaklanan haksız eleştirilere de maruz kalınmı̧̧tır. Söz gelimi İmam Gazzâlînin Tehafitül-Felasife adlı eserinde felsefecilere yaptı̆̆ı eleştiri yüzünden İslâm dünyasında felsefenin önünü kestiği ve felsefî anlayışın gelişmesine engel olduğu şeklinde iddialarda bulunan çok kimseyle karşılaşırız. Halbuki bu iddiayı dile getirenler, İslâm dünyasında felsefenin gelişmemesinin asıl sebeplerinden birisinin, döneminin Hadis ve

96 Bk. Ali İmran 3/32, 132.

97 “Ey iman edenler! Allah'a itaat edin. Peygamber'e ve sizden olan ulu'l-emre de itaat edin." en-Nisa 4/59.

98 İbn Cevzî, Ebu'l-Ferec Cemaluddin Abdurrahman b. Ali, Zadu'l-müyessir fî ilmi't-tefsir (Beyrut: el-Mektebetu'l-İslâmî, 2002), 294, 295.

99 Ebu Abdullah İmam Mâlik b. Esen el-Esbehî, el-Müdâvenetül-kübrâ (el-Memleketu’1-Arabiyyetu’s-Suudiyye: Vezaretu's-Sufûni'l-İslâmî, ts.).

100 Cemil Meriç, Saint-Simon İlk Sosyolog, İlk Sosyalist, 2. Baskı (İstanbul: İletişim Yayınları, 1996), 87. 
Fikıh uzmanı meşhur âlim İbn Salah'ın felsefeyi yasaklayan fetvasından ${ }^{101}$ kaynaklandığından habersizdirler.

İslâm uleması arasında ciddi ve sert eleştirilerin olduğu muhakkaktır. Ancak İslâm dünyasında gerek itikadî ve gerekse fikhî mezheplerin oluşum sürecinde, mezhebin merkezi bir yer alması hasebiyle zaman zaman taassubun ağır bastığını, maksadını aşan eleştirilerin olduğunu belirtmemiz gerekir. Zaman geçtikçe eleştirilerin dozunun düştüğü farkedilmektedir. Bunu, İslâm dünyasının geçirdiği sosyal, siyasî ve dinî tecrübenin etkilerinden bağımsız düşünmek bizi yanıltacaktır. Mezhepler arasında kavganın olduğu dönemlerde eleştirlerin çok sert, mezhepler arasındaki çekişmenin tarihe karıştığ dönemlerde ise eleştirinin olabildiğince yumuşak ve yapıcı olduğunu müşahade etmekteyiz. Yukarıda da işaret ettiğimiz gibi, ilk dönemlerde bazı ulema Ebu Hanife'yi çok sert bir şekilde eleştirmekten geri durmazken, mezhebi taassubun kaybolduğu dönemlerdeki genel havanın etkisiyle bu tarz eleştirilerin haksız olduğu da vurgulanmıştır. Bunun en bariz örneğini İmam Azam Ebu Hanife ile ilgili tavrı takip ederek tespit edebiliriz. İmam Eş'arî (330/941), Makâlatu'l-İslâmiyyîn adlı eserinde sapık bir mezhep olarak söz ettiği Mürcie'yi tanıtırken Ebu Hanife hakkında çok sade ve eleştiri yapmadan Mürcie'nin alt (dokuzuncu) sıralarında söz etmekle yetinirken, ${ }^{102}$ mezhepler arasında sosyal barışın sağlandı̆̆ 1 bir dönemde yaşayan Şehristânî (330/941) ise, Ebu Hanifeyyi Sünnî Mürcie'den sayarak $^{103}$ bu aykırılı̆̆g gidermeye çalışmı̧̧ır.

Yukarıda İmam Malik’in, İmam Azam’ı eleştirmesi ve Malikî mezhebinden olan İbn Abdilberr'in değerlendirmesini bu meyanda görmek gerekir. Keza Şafî̂ ve Malikî mezheplerine mensup olan kimselerden elinden gelseydi cizye alacağını ifade eden Hanefî mezhebinden birine, mezhepler arasındaki buzların eridiği bir dönemde yaşayan ve aynı mezhepten olan İbn Kutluboğa çok sert bir ifadeyle karşı çıkmasını da bu meyanda değerlendirmek gerekir.

Her insanın doğuştan getirdiği yetenekleri, zekâsı, yetiştiği çevre ve aldığg eğitim farklı olduğu müddetçe fikirler de farklı olacaktır. Dolayısıyla insanlar düşündükçe ve düşüncelerini dile getirdikçe, fikirlerdeki ayrılık devam edecek, bu durum sürdükçe de eleştiri her zaman var olacaktır. Önemli olan eleştirinin hasmını küçük düşürücü ve şahsiyet haklarına tecavüz edici olmamasıdır. Fikirler ve görüşler, deliller ortaya konmak şartıyla her zaman eleştirilebilmelidir.

\section{Kaynakça}

Ahmed b. Hanbel. el-Müsned. 2. Baskı. Beyrut: Daru İhyai't-Turasi'1-Arabî, 1993.

Ahmed Emin. Fecrül-islâm. Beyrut: Dârü'l-Kitabi'l-Arabî, 1969.

Amedî, Ebu Hasan Ali b. Muhammed. el-İhkâm fî usuliłl-ahkâm. thk. Seyyid el-Cumeylî, Beyrut: Daru'l-Kitabi'l-Arabî,1404.

Annemarie Schimmel. Doğudan Batıya. trc. Ömer Enis Akbulut, İstanbul: Sufî Kitap Yayınları, 2017.

101 İbn Salah, Takiyuddin Ebu Amr Osman İbn Müfti Salahuddin eş-Şehrezûrî, Feteva ve mesâil li ibn salah (Ma'âhu Edebu'l-Müftî ve’l-Müstasfî̀), thk. Abdülmu'tî Emin Kal'acî (Beyrut: Dârül-Ma'rife, 1986), 209, 210.

102 Ebu'l-Hasan Ali b. İsmail el-Eş'arî, Makâlatu'l-islâmiyyîn ve ihtilâfu'l-musallîn, thk. Muhammed Muhyiddin Abdulhumeyd (Beyrut: Mektebetu'l-Asriyye, 1990), 1: 219 vd.

103 Şehristânî, el-Milel ve'n-nihal, 1: 164. 
Bağdâdî, Ebu Mansur Abdülkahir b. Zahir b. Muhammed. el-Farku beyne'l-firâk. thk. Muhammed Osman el-Haşî, Kahire: Mektebetu İbn Sinâ, ts.

Bağdadî, Hafiz Ebubekir Ahmed b. Ali el-Hatib. Tarihu Bağdat ve medinetu's-selam. Beyrut: DârülKutubi'l-İlmiye, ts.

Bağdadî, Hafız Ebubekir Ahmed b. Ali el-Hatib. Tarihu medinetis'selam. Beyrut: Dârü'l-Garbi'1-İlmî, 2001.

Beyhakî, Ebu Bekir Ahmed b. Hüseyin, el-Cami’ liş̧-Şu'abil-İman. thk. Abdulali Abdülhamid Hamid, Riyad: Mektebetu'r-Rüşd, 2003.

Bîrûnî, Ebưr-Reyhân Muhammed b. Ahmed. Fî tahkîk mâ li'l-Hind. Matbaâtu'Meclisi Dâireti'1Me'ârifi'l-Osmâniyye, 1958.

Buharî, Ebu Abdullah Muhammed b. İsmail. Sabihu'l-buharî. İstanbul: Mektepetu'l-İslâmî, ts.

Cahız, Ebu Osman Amr b. Bahr. el-Heyerân. thk. Abdusselam Muhammed Harun, 2. Baskı. Misır: Matbaatu Mustafa el-Babî, 1966.

Campbell, Karlyn Kohrs. Critiques of Contemporary Rhetoric. Belmont, Ca.: Wadsworth Publishing Company, 1972.

Chokr, Melhem. İslâmın Hicri İkinci Asrında Zındıklık ve Zındıklar. trc. Ayşe Meral, İstanbul: Anka Yayınlar1, 2002.

Coşkun, Selçuk. Hadise Bütüncül Bakış. İstanbul: İFAV Yayınları, 2011.

Cüveynî, Ebu'l-Mealî Abdülmelik b. Abdullah b. Yusuf. el-Burhan fî usûli’l-fikh. Katar: thk. ve nşr. Abdülazim ed-Dîb, 1399.

Ebu'l-Abbas Şemsuddin Ahmed b. Muhammed b. Ebibekir b. Hallikan. Vefayatu'l-a'yan ve enbau ebnai'z-zaman. thk. İhsan Abbas, 4. Baskı. Beyrut: Daru Sadr, 2005.

Ebu'l-Ferec Abdurrahman b. Ali b. Muhammed İbnu'l-Cevzî. el-Muntazam fîtaribi'l-muluk ve'l-umem. thk. Muhammed Abdulkadir Ata, Mustafa Abdulkadir Ata, Beyrut: Dârü'l-Kutubi'l-İlmiye, 1992.

Enbarî, Ebu'l-Berakât Kemaluddin Abdurrahman b. Ahmed. Nüzhetu'l-elbâa fî tabakati'l-udebâ. thk. Muhammed Ebu'l-Fadl İbrahim, Kahire: Dârü'l-Fikri'l-Arabî, 1998.

Eş'arî, Ebu'l-Hasan Ali b. İsmail. Makâlatu'l-islâmiyyîn ve ihtilâfu'l-musallîn. thk. Muhammed Muhyiddin Abdulhumeyd, Beyrut: Mektebetu'l-Asriyye, 1990.

Fahruddin er-Razî, Muhammed b. Ömer b. Hüseyin. Tefsiru'l-kebir (Mefatihu'l-gayb). Beyrut: Dârü'lFikr, 1981.

Fahruddin er-Razî, Muhammed b. Ömer b. Hüseyin. Menâkibu’̧̧-Şafî̀, thk. Ahmed Hicazî eş-Şakkâ. Kahire: Mektebetu'l-Külliyâti'l-Ezheriyye, 1986.

Gazzâlî, Ebu Hamid Muhammed b. Muhammed. el-Mustasfâ min ulumi'l-usûl. thk. Hamza b. Züheyr Hafız, el-Medinetu'l-Münevvere: ts.

Gazzâlî, Ebu Hamid Muhammed b. Muhammed. Mekasidu'l-felasife. thk. Mahmud Dubeycu, Dımaşk: Matbaatu'l-Debbah, 2000.

Gözütok, Şakir. "İslam Dünyasında Medreseler ve İhtisas Medreselerinin Doğuşu”. Uluslararası medreseler ve modernleşme sürecinde medreseler sempozyumu. Muş: Muş Alpaslan Üniversitesi Yayınlar1, 2012, 2: 2-19.

Gutas, Dimitri. İbn Sinẩnın mirası. Der: M. Cüneyt Kaya, İstanbul: Klasik Yayınları, Mart, 2004.

Hafız Ebubekir Ahmed b. Ali el-Hatib el-Bağdadî. Tarihu Bağdat ve medinetu's-selam. Beyrut: Dârü'1Kutubi'l-İlmiye, ts.

Hakim en-Neysaburî, Ebu Abdullah Muhammed b. Abdullah, Müstedrek alâ Sabihayn. thk. Mustafa Abdulkadir Ata, Beyrut: Daru'1-Kutubi'l-İlmiye, 1990. 
Hitti, Philip K., Siyasi ve Kültürel İslam Taribi. trc. Salih Tuğ, İstanbul: İFAV Yayınları, 2011.

İbn Abdilberr, Ebu Ömer Yusuf b. Abdilberr. Cami'u'l-beyani'l-ilm ve fadlibi. thk. Ebu'1-Eşbar ez-Zührî, Suudi Arabistan: Dâru İbni'l-Cevzî, ts.

İbn Adim, Sahib Kemaluddin b. Ahmed b. Ebi Cerade. Buğyetu't-taleb fî taribi Haleb. thk. Süheyl Zekâr, Beyrut: Dârü'l-Fikr, ts.

İbn Adiyy, Ebu Ahmed Abdullah b. Adiyy el-Cürcanî. el-Kâmil fî du'afaìr-rical. thk. Adil Ahmed Abdulmevcud, Ali Muhammed Mu’avvid, Beyrut: Dârü'l-Kutubi'l-İlmiyye, ts.

İbn Cevzî, Ebu'l-Ferec Cemaluddin Abdurrahman b. Ali. Zâdu'l-müyessir fî̀ ilmi't-tefsir. Beyrut: elMektebetu'l-İslâmî, 2002.

İbn Ebi Şeybe, Ebu Bekir Abdullah b. Muhammed b. İbrahim, Musannaf. thk. Hamad b. Abdullah elCum'a, Muhammed b. İbrahim, Riyad: Mektebetu'r-Rüşd, 2004.

İbn Ebi Ya’lâ, Kadı Ebu Hüseyin Muhammed b. Ebi Ya’lâ. Tabakâtüll-henâbile. Beyrut: Daru'1-Ma'rife, ts.

İbn Hallikan, Ebu'l-Abbas Şemsuddin Ahmed b. Muhammed b. Ebibekir. Vefayatu'l-a'yan ve enbau ebnai'z-zaman. thk. İhsan Abbas, 4. Baskı. Beyrut: Daru Sadr, 2005.

İbn Hazm, Ebu Muhammed Ali b. Ahmed b. Said b. Hazm el-Endelûsî. el-Î́âl fî̀l-muhallâ bi'l-âsâr. thk. Abdulgaffar Süleyman el-Bindârî. Bayrut: Daru'l-Kutubi'l-İlmiyye, 2003.

İbn Hibban Ebu Hatim. Sabihu ibn hibban bi't-tertibi ibn balban. Telif: Alauddin Ali b. Balban el_Farisî, thk. Şuayb Arnaut, Beyrut: Müessesetu'r-Risale, ts.

İbn Kuteybe, ed-Dineverî. Kitabu te’vîli mubtelefi'l-hadis. Kahire: Mektebetu'1-Mütenebbî, ts.

İbn Kutluboğa, Ebu'l-Fidâ Zeybuddin Kasım b. Kutluboğa es-Sudûnî. Tacu't-teracim. thk. Muhammed Hayr Ramazan Yusuf, Dımaşk: Dârü'l-Kalem, 1992.

İbn Mukaffa', Abdullah b. Mukaffa'. Risaletu fî̀s-sahabe (Asaru ibn Mukaffa' içinde). Beyrut: Dârü'lKutubi'l-İlmiyye, 1989.

İbn Munzur. Lisanu'l-arab. Tah: Abdullah Ali el-Kebir, Muhammed Abdullah Hasbullah, Haşim Muhammed Şazelî, Kahire: Dârü'l-Mer'arif, ts.

İbn Sa'd Muhammed b. Sa'd b. Müni’ ez-Zührî, Tabakatu'l-Kebir. thk. Ali Muhammed Ömer, Kahire: Mektebetu'l-Hancî, 2001.

İbn Salah, Takiyuddin Ebu Amr Osman İbn Müfti Salahuddin eş-Şehrezûrî. Feteva ve mesâil li ibn salah (Ma'âhu edebu'l-müftî ve'l-müstasfî). thk. Abdülmu'tî Emin Kal'acî, Beyrut: Dârü'l-Ma'rife, 1986.

İbn Teymiyye, Ebu'l-Abbas Takyiddun Ahmed b. Abdülhalim. ed-Der'u te'aridil-akl ve'n-nakl. thk. Muhammed Reşad Salim, Medine: Vizeratu't-Ta’limi'l-Alî, 1991.

İbni Kayyım el-Cevziyye. I'lamu'l-muvak'în. thk. Taha Abdurrauf Sa'd, Beyrut: Dârü'l-Ceyl, 1973.

İbni Kesir İmaduddin Ebu'1-Fida Hafiz. el-Bidaye ve'n-nihaye. thk. Abdullah b. Abdilmuhsin et-Turkî, Beyrut: Dârü'l-Hicr, 1997.

İbnu'l-İmad Şihabuddin Ebu Ferec Abdulhayy b. Ahmed b. Muhammed el-Akrî ed-Dımaşkî. Şezeratu'z-zeheb fî abbari men zeheb. thk. Abdulkadir el-Arnaut, Mahmud el-Arnaut, Beyrut: Dâru İbni Kesir, 1986.

İmam Mâlik Ebu Abdullah b. Esen el-Esbehî. el-Müdâvenetül-kübrâ. el-Memleketu'1-Arabiyyetu'sSuudiyye: Vezaretu's-Sufûni'l-İslâmî, ts.

İsfehanî, Ebu Kasım Hüseyin b. Muhammed Radıb. el-Müfredat fî garibi'l-Kur'ân. thk. Muhammed Seyyid Geylanî, Beyrut: Dârü'l-Ma'rife, ts.

İsfehanî, Ebu'1-Ferec Ali b. Hüseyin. Kitabu'l-eğanî. thk. Abdullah Ali Maha, Beyrut: Dârü'1-Kutubi'1İlmiye, ts. 
Kadı Ali b. Ali b. Muhammed b. Abdulizz ed-Dımaşkî. Şerbu'l-akideti't-tehavî. thk. Abdullah b. Abdulmuhsin et-Turkî ve ŞuaybU21-Arnaûtî, Beyrut: Müessesetu'r-Risale, ts.

Karşî, Muhyiddin Ebu Muhammed Abdulkadir b. Muhammed. el-Cevahiru'l-madiye fî tabakati’lbanefiye. thk. Abdulfettah Muhammed el-Halvi, 2. Bask1. Beyrut: Daru Hicr, 1993.

Kehhale, Ömer Rıza. A'lamu’n-nisa fî âlemi'l-Arab ve'l-İslam. Beyrut: Müessesetu’r-Risale, ts.

Kindî. Felsefî Risaleler. trc. Mahmut Kaya, İstanbul: İz Yayınları, 1994.

Kindî. Resâilu'l-Kindî el-Fesefiyye. thk. Muhammed Abdulhadi Ebu Zeyde, Misır: Daru'l-Fikri'1Arabî, 1950.

Kurtubî, Ebu Abdullah Muhammed b. Ahmed b. Ebubekir Şemsuddin. el-Cami' li'l-abkâmi'l-Kur'ân. thk. Hişam Sümeyr el-Buharî, Riyad: Daru Alemi'l-Kutub, 2003.

Kutay, Cemal. Bilinmeyen Taribimiz. İstanbul: Dizerkonca Matbaası, 1974.

Makrizî,Takiyuddin Ebu'1-Abbas Ahmed b. Ali b. Abdilkadir. el-Mevaizu ve'l-i'tibar bi zikri'l-bitat ve'lasar. thk. Halil el-Mansur, Beyrut: Dârü'1-Kutubi'l-İlmiye, 1998.

McPeck, John E. Critical thinking and education. New York: Reotledge, 1981.

Meriç, Cemil. Mağaradakiler. İstanbul: Ötüken Yayınları, 1978.

Muhammed Ebu Zehra. İmam Şafî̀. trc: Osman Keskioğlu, Ankara: D.İ.B. Yayınları, 1987.

Müslim Ebu Hüseyin b. Haccac el-Kuşeyrî en-Neysaburî. Sabibu’l-müslim. 2. Baskı. Beyrut: Dâru İhyai't-Turas i'l-Arabî, 1972.

Nevevî, Ebu Zekeriya Muhyiddin b. Şeref. el-Mecmu'şerhu'l-mühezzeb lişs-şirâzî. thk. Muhammed Necib el-Muti'î, Cidde: Meketebetu'l-İrşad, ts.

Öz, Şaban. “Asım Köksal'ın Caetani Reddiyesi Üzerine”. İslâmî Araştırmalar Dergisi, (2004), 17 (3): 162-170.

Özen, Şükrü. “İmam Ebu Mansur el-Maturidînnin Fıkıh Usûlünün İnşâsı”. İmam Maturudî ve Maturidîlik, Haz: Sönmez Kutlu, Ankara: Kitabiyat Yayınları, 2003, 203-242.

Pezdevî, Ebu'1-Yusr Muhammed. Usûlu'd-din. thk. Hans Peter Linns, Kahire: el-Meketebtu'l-Ezheriyye li't-Turas, 2003.

Rudolph, Ulrich. Maturidî. trc. Özcan Taşlı, İstanbul: Litera Yayınları, 2016.

Safedî, Selahuddin Halil b. Aybek. el-Vafî bìl-vefeyât. thk. Ahmed Arnaut ve Tezkî Mustafa, Beyrut: Dâru İhyai't-Turasi'l-Arabî, 2000.

Sem'anî, Ebu Sa’d Abdülkerim b. Muhammed. B. Mansur et-Temimî. el-Ensab. thk. Abdurrahman b. Yahya el-Mu'allimî, 2. Baskı. Kahire: Mektebetu İbn Teymiyye, 1980.

Şemsuddin es-Serâhsî. el-Mebsût. Beyrut: Daru'l-Ma'rife, ts.

Subkî, Tacuddin Ebu Nasr Abdulvahhab b. Ali b. Abdilkafî. Tabakatu’ş-şafî̀yyeti'l-kübrâ. thk. Mahmud Muhammed et-Tanahî, Abdulfettah Muhammed el-Hulvî, Kahire: Dâru İhyai'l-Kutubi'l-Arabî, ts.

Suyutî, Abdurrahman Celaluddin. Nuzulu İsa fî abiri'z-zaman. thk. Sa'd Kerim ed-Dir'amî, İskenderiye: Dâru İbn Haldun, ts.

Şafî̂, Muhammed b. İdris. el-Umm. thk. Muhammed Zühri en-Neccar, Beyrut: Dârü'l-Ma'rife, ts.

Şatibî, Ebu İshak İbrahim b. Musa b. Muhammed. el-İtisam. thk. Ebu Ubeyde Meşhur b. Hasan Âl Süleyman, Kahire: Mektebetu't-Tevhid, ts.

Şehristanî, Ebu'l-Feth Muhammed b. Abdülkerim b. Ebibekr Ahmed. el-Milel ve'n-nibal. thk. Emir Ali Mehnâ, Ali Hasan Fa'ûr, 3. Baskı. Beyrut: Dârü'l-Ma’rife, 1993.

Taberî, Ebu Ca'fer Muhammed b. Cerir, Tarihu't-Taberî Tarihu'r-rusul ve'l-mulîk. thk. Muhammed Ebu'l-Fadl İdrahim, Misır: Daru'l-Me'arif, ts. 
Tevhidî, Ebu Hayyan. el-İmtâ' ve'l-mu'ânese. thk. Heysem Halife et-Ta'imî. Beyrut: el-Mektebetu'lAsriyye, 2011.

Tevhidî, Ebu Hayyan. el-Mukāabesât, thk. Hanna et-Tendûlî, 2. Baskı. Kahire: Daru Se’adi’s-Sibah, 1992.

Tirmizî, Ebu İsa Muhammed b. İsa. Sünenu't-Tirmizî. thk. Ahmed Muhammed Şakir, Beyrut: Dâru'tTurasi'l-İlmiye, ts.

Yakut el-Hamevî, Şihabuddin Ebu Abdullah Yakut b. Abdullah el-Hamevî. Mưcemu’l-udeba irşadu’lerib ilâ ma'rifeti'l-edib. Beyrut: Dârü'l-Kutubi'l-İlmiye, 1991.

Yazıcıoğlu, Sait. "Maturidî Kelam Ekolünün İki Büyük Siması: Ebu Mansur Maturidî ve Ebu'1-Öu'in Nesefî”. İmam Maturudî ve Maturidîlik, Haz: Sönmez Kutlu, Ankara: Kitabiyat Yayınları, 2003, 155-172.

Zehebî, Şemsuddin Ebu Abdullah Muhammed b. Ahmed b. Osman. Siyeru a'lami’n-nubelâ. thk. Şuayb Arnaut, Beyrut: Müessesetu'r-Risale, 1984.

Zehebî, Şemsuddin Ebu Abdullah Muhammed b. Ahmed b. Osman. Tarihu'l-islâm ve vefayatu'l-meşahir ve'l-a'lâm. thk. Ömer Abdusselam Tedmurî, Beyrut: Dârü'l-Kitabi'l-Arabî, 1993.

Zehebî, Şemsuddin Ebu Abdullah Muhammed b. Ahmed b. Osman. Miz^nu'l-ìtidâl fî̀ nakdìr-ricâl. thk. Ali Muhammed el-Becâvî, Beyrut: Dârü'l-Ma'rife, ts. 


$$
\text { NR? }
$$

